\title{
İnternet Bağımlılık Düzeyinin Akademik Ertelemeye Etkisi: Sağlık Yönetimi Öğrencileri Üzerine Bir Araştırma
}

\section{Kürşat YURDAKOŞ*, Enis Baha BICÇER**}

Öz: $\mathrm{Bu}$ çalışmayla, sağlık yönetimi bölümünde okuyan üniversite öğrencilerinin internet bağımlılık düzeylerinin akademik ertelemeleri üzerindeki etkisinin ölçülmesi amaçlanmaktadır. Araştırma verileri Sivas Cumhuriyet Üniversitesi 2017-2018 öğretim yılında öğrenim gören 1., 2., 3. ve 4. sınıf öğrencilerini kapsamaktadır. Araştırma, kesitsel ve tanımlayıcı tipte olup, 49’u 4. sinıf, 55'i 3. sınıf, 55'i 2. sinıf ve 63'ü 1. sinıf olmak üzere 222 öğrenci üzerinden yürütülmüştür. Veriler, araştırmacı tarafından geliştirilen demografik bilgi formu, Akademik Erteleme Ölçeği (AEÖ) ve İnternet bağımlılığı Ölçeği (İBÖ) aracılığıyla elde edilmiştir. Elde edilen sonuçlar, sınıflama tabloları, t-testi, tek yönlü ANOVA, basit doğrusal regresyon analizi ve korelasyon analizi yöntemleri aracılığıyla doğrulanmış ve karşılaştırılmıştır. Araştırma kapsamındaki öğrencilerin \%51,4’ü internet bağımlısı değil, $\% 45,5$ 'i riskli kullanıcı, \%3,2'si ise internet bağımlısı olarak belirlenmiştir. Öğrencilerin akademik erteleme algılarının cinsiyete $(\mathrm{t}=2,075 ; \mathrm{p}<0,05)$, Genel Akademik Not Ortalamaları'na (GANO) $(\mathrm{F}=7,089 ; \mathrm{p}<0,05)$ ve alttan ders almalarına $(\mathrm{t}=-2,556 ; \mathrm{p}<0,05)$ göre farklılı̆̆ın istatistiksel olarak \%95 güven seviyesinde anlamlı olduğu belirlenmiştir. Öğrencilerin internet bağımlılığı algılarının cinsiyete $(\mathrm{t}=-4,832 ; \mathrm{p}<0,05)$, yaş gruplarına $(F=2,688 ; \mathrm{p}<0,05)$, GANO’ya $(F=4,678 ; \mathrm{p}<0,05)$ göre farklılığın istatistiksel olarak \%95 güven seviyesinde anlamlı olduğu belirlenmiştir. Bu sonuçlara göre; internet bağımlılığının akademik erteleme üzerinde anlamlı bir etkiye sahip olduğu görülmektedir.

Anahtar Sözcükler: Akademik erteleme, internet bağımlılı̆̆ı, sağlık yönetimi, üniversite öğrencileri.

\footnotetext{
* Öğretim Görevlisi, Cumhuriyet Üniversitesi, Yıldızeli Meslek Yüksekokulu, Tıbbi Hizmetler ve Teknikleri Bölümü, İletişim: kyurdakos@cumhuriyet.edu.tr Orcid ID, 0000-0002-1473-5513

** Dr. Öğretim Üyesi, Cumhuriyet Üniversitesi, Sağlık Bilimleri Fakültesi, Sağlık Yönetimi Anabilim Dalı, İletişim: ebbicer@cumhuriyet.edu.tr Orcid ID, 0000-0002-1624-4988
}

\begin{tabular}{lll}
\hline Gönderim:27.09.2018 Kabul:09.01.2019 $\quad$ Yayın:15.03.2019
\end{tabular}




\section{The Effect of Internet Addiction Level on Academic Procrastination: A Research on}

\section{Health Management Students}

Abstract:This study aims to measure the effect of internet addiction levels of university students studying in health management department on academic procrastination. The research data include the 1st, 2nd, 3rd, and 4th year students of Sivas Cumhuriyet University in 2017 2018 academic year. The research is a cross-sectional and descriptive type and it consists of 222 students, 49 of whom are 4th grade, 55 are grade 3, 55 are 2nd grade and 63 are 1st grade. The data were obtained through the demographic information form developed by the researcher, the Academic Procrastination Scale (ESI) and the Internet Addiction Scale (PPI). The results were verified and compared by means of classification tables, t-test, one-way ANOVA, simple linear regression analysis and correlation analysis methods. $51.4 \%$ of the students in the study were determined as not internet addicts, $45.5 \%$ were as risky users and $3.2 \%$ were as internet addicts. It is determined that the students' academic procrastination perceptions of gender is $(t=2,075$; $p<0,05)$, their general academic grade average (GANO) is $(\mathrm{F}=7,089 ; \mathrm{p}<0,05)$ and their taking lessons from the lower classes is $(\mathrm{t}=-2,556 ; \mathrm{p}<0,05)$, and they are statistically significant at 95\% confidence level.

It was determined that there was a meaningful difference between the students' perceptions of internet addiction and gender $(\mathrm{t}=-4,832 ; \mathrm{p}<0,05)$, age groups $(\mathrm{F}=2,688 ; \mathrm{p}<0,05)$ and GANO $(\mathrm{F}=4,678 ; \mathrm{p}<0,05)$ at $95 \%$ confidence level statistically. According to these results, Internet addiction has a significant effect on academic procrastination.

Keywords: Academic procrastination, Internet addiction, health management, cross-sectional

\section{Giriş}

İnternet hayatımızda giderek büyüyen bir rol oynamaktadır. Bu durum yetişkinlere göre genç neslin hayatında daha da büyük bir düzeyde gerçekleşmektedir (Amichai Hamburger, 2013). Dolayısıyla kişisel bilgisayarlar, milyarlarca insan tarafından kişisel ve profesyonel yaşamlarının her alanında kullanılmaktadır. Günümüz toplumunda dünya nüfusunun yaklaşık \%40’ının çevrimiçi ve küresel internet kullanımı son on yılda yaklaşık altı kat büyümüştür. Kore'de internet kullanıcılarının \%96’sı, Birleşik Krallık'tan \%78'lik ve ABD’den \%56'lık 
oranla yüksek hızlı internet bağlantılarını kullanmaktadır (International Telecommunication Union [ITU], 2012, 2013).

İnternet dünya çapında ağ oluşturmayı kolaylaştırırken, birçok bilgi ve hizmete 24 saat erişim sağlamıştır. Sosyal ağ siteleri (SNS), kullanıcılarına çok sayıda hizmet sunan, teknoloji güç merkezleri olarak büyümeye devam etmektedirler. (T.P. Alloway, Horton, R.G. Alloway ve Dawson, 2013). SNS kullanıcıları, Facebook’ta kişisel bilgileri yüklemekten, YouTube'da nasıl yemek yapılacağına dair bir video izlemekten, Whatsapp/Skype üzerinden gerçek zamanlı sohbet konuşmalarına, düzeyler oluşturmaya ve dünyanın dört bir yanından insanlar/kişiler birlikte karşılıklı oynamaya geçebilir. Kullanıcılar bunu çeşitli çevrimiçi oyunlar ve platformlar aracılığıyla yapabilirler. Örneğin, The Xbox ve PlayStation konsolları ve akıllı telefon/tablet oyun uygulamaları gibi. Bu özelliklerin her biri sadece bir ya da başka bir teknolojik platformla sınırlı değildir. Günümüz sosyal ağ uygulamalarının çoğu, birden fazla cihazda mevcuttur ve çoğu zaman birbirleriyle senkronize ve birbirine bağlanabilir. İnsanların, birden fazla seçtikleri sosyal ağ uygulamalarını kontrol etme fırsatına sahip oldukları açıktır. Türkiye'de sırasıyla youtube, mynet, msn, indir, mp3 ve facebook siteleri kullanılırken, Almanya'da alışveriş (ebay), youtube, iletişim (gmx-eposta), hava durumu, yol durumu, sözlük ve telefon rehberi, Fransa'da bilgi arama, skyblog, meteo, yahoo, msn ve İngiltere'de ise daha çok haber, oyun, alışveriş, bilgi arama siteleri kullanılmaktadır (Ocak, 2012). 2019 yılında Türkiye'de sosyal medya kullanım istatistiklerinde; toplam 52 milyon sosyal medya kullanıcısı olup, bu kullanıcıların 44 milyonu mobil cihazlar ile sosyal medyaya bağlantı yapmışlardır. En aktif sosyal medya platformu sıralaması ise Youtube, Instagram, Facebook, Twitter, Snapchat ve LinkedIn’dir. 2019 yılı mobil kullanıcı istatistiklerinde mobil kullanıc1 sayıs1 76.3 milyon olup, bu oran Türkiye nüfusunun \%93’üne denk gelmektedir. 2019 Türkiye e-ticaret istatistiklerine göre ise en çok harcama sırasıyla seyahat, elektronik ürünler, moda ve güzellik ürünleri, oyuncak ve hobi ürünlerine yapılmıştır (Bayrak, 2019).

Teknolojinin gelişmesiyle internete erişim hızının artması ve ulaşım sağlayan cihaz çeşitliği internet kullanıcı sayısında büyük artışa sebep olmuştur (Murathan, 2018). Avrupa İstatistiklerine göre, yirmi sekiz ülkenin üye olduğu Avrupa Birliği'nde 2016 yılı sonu itibarı ile hanelerin \%85'inin internet erişimine sahip olduğu, bireylerin \%82'sinin son üç ay içinde, \%79'unun düzenli olarak ve \%71'inin her gün interneti kullandığı; 16-74 yaş arasındaki bireylerin \%86'sının özel amaçlarla e-mail gönderme ve \%80'inin bilgi edinme amaciyla interneti kullandığı bildirilmiştir (Pınar Bölüktaş, Özer ve Yıldırım, 2019). Türkiye’de bilgisayar ve internet kullanımı 2017 yılında 16-74 yaş grubundaki bireylerde sırasılya \%56,6 
ve $\% 66,8$ 'dir. $\mathrm{Bu}$ oranlar 2016 y1lında sırasıyla $\% 54,9$ ve $\% 61,2$ olmuştur. Bilgisayar ve İnternet kullanım oranları 16-74 yaş grubundaki erkeklerde \%65,7 ve \%75,1 iken, kadınlarda \%47,7 ve \%58,7’dir (Türkiye İstatistik Kurumu [TÜİK], 2017).

İnternet kullanımının artan popülaritesi ve sıklığı, kötüye kullanım belirtileri gösteren klinik vakaların ortaya çıkmasına neden olmuştur. 1996 yılında İnternet Bağımlılığı Bozukluğu (IBB) kavramı ilk olarak gündelik davranışların algılanan patolojisine yanıt olarak neşeli bir aldatmaca olarak ortaya çıkmıştır (Goldberg, 1996). Hem çevrimiçi hem de çevrimdış1 alanlarda, kullanıcılar farklı firsatlar ve riskler yaşamaktadırlar. Fırsatların büyük ölçüde iyimserlik ve kamu/özel sektör hükümlerinin olduğu heterojen bir dizi faaliyet, öğrenme, iletişim, yaratıcılık, ifade ve eğlenceyi kapsadığı düşünülmektedir. Ancak bunun tersine, riskler, kendine zarar verme, şiddet, 1 rkçılık, nefret yada taciz yoluyla nefret uyandıran temaslar ve akranlar arasında zorbalık yada gizlilik istilası gibi sorunlu davranışlar da dahil olmak üzere istenmeyen deneyimlerin heterojenliğini de kapsamaktadır (Livingstone ve Haddon, 2008).

Google tarafından gerçekleştirilen araştırmada, 2017 yılında Türkiye'de en çok arananlar raporuna göre; dizi, genel aramalar, nedir, yemek tarifi, ünlüler ve şarkı şeklinde 6 farklı kategori belirlenmiştir. İçerik olarak en çok aranan ilk üç terim ise; dizi başlığı altında; game of thrones, fi, içerde; genel aramalar başlığg altında; milli piyango, stres çarkı, e-okul; nedir başlığı altında; pestisit, varlık fonu, chia tohumu; yemek tarifi başlığı altında; krep, aşure, güllaç; ünlüler başlığı altında; Vatan Şaşmaz, Filiz Aker, İbrahim Erkal; şarkı başlığı altında ise gece gölgenin rahatına bak, sen olsan bari erik dalı gevrektir olmuştur (Seo Hocası, 2017).

Ergenlerde internet bağımlılığının yaygınlığı ile ilgili olarak yapılan araştırmalar ülkeler arasında büyük farklılıklar göstermektedir. Young (1999), İnternet Bağımlılığı Testini kullanarak gerçekleştirmiş olduğu araştırmasında, Yunanlıların \%1,5'inin ve Fin ergenlerin \%1,6’sının interneti kullanmaya bağımlı olduklarını tespit etmiştir. Liu, Desai, Krishnan-Sarin, Cavallo ve Potenza (2011) ise Minnesota İmpulsif Bozukluklar Envanterinin değiştirilmiş bir versiyonunu kullanarak, ABD'deki lise öğrencilerinin \%4'ünün interneti kullanmaya bağımlı olduklarını belirlemiştir. Işık ve Ergün (2018) tarafından yapılan araştırmada, ergenlerin, internet ve teknoloji kullanımı bağımlılığı bakımından önemli bir risk grubunu oluşturduğunu ve Türkiye'de 12-18 yaş grubu gençlerin yüzde 3,6'sının internet ve teknoloji bağımlısı, yüzde 21,8'inin ise bağımlılık sınırında olduğunu tespit etmişlerdir. Güney Doğu Asya ülkelerinde daha yüksek yaygınlık oranları bildirilmiştir (Tayvan, Singapur, Güney Kore ve Çin). Örneğin, Cao, Sun, Wan, Hao ve Tao (2011) İnternet Bağımlılığı Testi’ni kullanarak Çin'deki ergenlerin 
\%8’inin, Park, Kim ve Cho (2008) ise Güney Kore'deki ergenlerin \%10.7’sinin interneti kullanmaya bağımlı olduklarını bulmuştur. Diğer taraftan, İnternet ve Bilgisayar Oyunu Bağımlılık Ölçeği'nin değerlendirilmesinde reşit olmayanlar arasında internet bağımlılığının yaygınlığı Almanya'da \%11,3 olarak bulunmuştur (Müller, Ammerschläger, Freisleder, Beutel ve Wölfling, 2012). İnternet Bağımlılığı Testi aracılığıyla değerlendirildiğinde, Latin Amerika'daki ergenlerin \%11.6’sı internet bağımlısı olarak sınıflandırılmıştır (Liberatore, Rosario, Colon-De Marti ve Martinez, 2011).

Yeni medyanın kullanılabilirliği ve hareketliliği ile birlikte, internet bağımlılığı, genç medya bilimi nesillerinde potansiyel bir sorun olarak ortaya çıkmıştır. Adölesan dönemdeki gençlerin sosyalleşmesinde, şahsiyet ve kimlik olgunlaşmasında, hayatı paylaştığı sosyal çevre ile kurduğu bağ kadar sanal platformdaki bağının da etkili olduğu aşikârdır. Ancak, internetin gençler üzerinde meydana getirdiği tesir, pozitif olduğu kadar negatif de olabilmektedir. Adölesan dönemde frontal korteks ve bir diğer nörobiyolojik sistemler genel olarak gelişmesini tamamlamadığından dolayı, gençlerin kendilerini kontrol altına alabilmeleri için ihtiyaç olan bilişsel ve duygusal becerilerinde eksiklik var olmaktadır (Kwon, 2011).

İnternet bağımlılığının da aynı kimyasal bağımlılıklar gibi birincil ve süreç içerisinde ilerleyen bir hastalık olduğu ifade edilmektedir (Chrismore, Betzelberger ve Tonya, 2011). Keyif verici davranışların bağımlılık yapıcı özellikleri bulunmakla birlikte, internetin ve dijital teknolojilerin keyif verici özellikleri bilinmektedir. Bu nedenle keyif verici duygu durum değişimi daha sonraki kullanım ihtimalini artırmaktadır (Greenfield, 2011). İnternet bağımlılı̆̆ı, bir psikolojik bağımlılık olup, özellikle gençler bu bağımlılık açısından riskli gruptur. İnternetin aşırı kullanımı sağlık, ilişki ve zaman yönetimiyle ilgili sorunlara neden olabilmektedir (Chou ve Hsiao, 2000). Problemli internet kullanımı, uyumsuz düşünce ve patolojik davranışları içeren bir psikiyatrik durumdur (Davis, 2001).

Sürekli veri akışı sadece üretkenliği engellemeyecek, aile uyumunu bozacak, daha da önemlisi çoğu durumda kapanması çok zor olan bir bağımlılık haline gelebilecektir (Ritchel, 2003). Yeni çalışmalar, ergenler arasında teknoloji bağımlılığının öğrenme üzerinde yıkıcı bir etkiye sahip olduğunu ortaya çıkarmıştır (Gorra ve Bhati, 2016; Kakabadse, Kakabadse, Bailey ve Myers, 2009). Ergenler, bilişsel kontrollerini ve sınır belirleme becerilerini geliştirmedeki değişkenlikten dolayı internet bağımlılığı geliştirme riski taşıyan bir topluluktur (Leung, 2007). Sosyal paylaşım siteleri hakkında 524 öğrenci üzerinde gerçekleştirilen araştırmada, sosyal paylaşım sitesinde geçirilen zaman, yaşantıyı ne açıdan olumsuz etkiliyor? sorusuna, katılımcıların \%45'i dersler, \%18'i arkadaşlar, \%16'sı aile, \%13'ü yaşa uygun olmayan içerik 
ve \%8'i sosyal etkinlik azlığı olarak ifade etmişlerdir (Ocak, 2012). Bu gibi durumlar akademik ertelemelere neden olabilmektedir. Erteleme kavramsal ve ampirik olarak sorumluluk yetisi, kendini disipline edebilme ve başarı motivasyonu ile ilişkilidir (Rabin-Laura, Fogel Joshua ve Nutter-Upham, 2011). Erteleme, psiko-sosyal olarak yorucu ve aynı zamanda yorucu olduğu kadar çok stresli de olabilmektedir (Sirois, 2016). Akademik erteleme ise imtihanlara hazır olma, dönemsel ödevleri hazır etme, okuluyla ilişkili yönetimsel planları yerine getirme gibi bazı ana akademik görevlerin zamanında yapılamaması ve son ana bırakılması şeklinde açıklanmaktadır (Solomon ve Rothblum, 1984). Yapılan araştırmada, üniversite öğrencilerinin yarısı, zamanlarının en az \%50'sinde akademik erteleme davranışı sergilerken, \%38'i ise bazen akademik erteleme davranışı sergilemiştir (Solomon ve Rothblum, 1984). Türkiye'de üniversitede gerçekleştirilen araştırmada, öğrencilerin \%53'ünün akademik erteleme davranışında bulundukları belirlenmiştir (Ulukaya ve Bilge, 2014). Akademik ertelemeyle, maksimum sıklıkla ders bırakma, geri kalma veya yetersiz öğrenme söz konusudur (Ackerman ve Gross, 2005). Yazma, okuma ve ders çalışma gibi akademik ertelemede bulunan öğrenciler sıklıkla yeme-içme, televizyon izleme, elektronik posta bakma, internette sörf gibi etkinliklere yönelmektedir (Klassen ve diğ., 2010). Kınık (2015) araştırmasında, akademik erteleme davranışının öğrenim görülen fakülteye ve günlük internet kullanım süresine göre anlamlı bir fark gösterdiğini tespit etmiştir. Diğer yapılan araştırmada, problemli İnternet kullanımı cinsiyete ve öğrenim görülen fakülteye göre farklılık göstermektedir (Odacı ve Berber Çelik, 2012). Uzun, Ünal ve Toker (2014) yaptıkları araştırmada üniversitedeki öğrencilerde, internet bağımlılığının bulunduğunu, akademik erteleme, genel erteleme ile İnternet bağımlılı̆̆ değişkenleri arasında önemli ilişki olduğunu tespit etmiştir.

Hemşirelik Yüksek Okulu öğrencilerine uygulanan araştırmada, öğrencilerin Zaman Yönetimi Envanteri puanları yükseldikçe akademik başarı puanlarının da yükseldiği belirlenmiştir (Başak, Uzun ve Arslan, 2008). Bu durum öğrencilerin bireysel yeteneklerini zora sokmayan, bireysel yetenekleri için uygun ve eğlenceli gördükleri akademik olan ve olmayan faaliyetleri, daha çok gayret gerektiren ve endişe oluşturan akademik olan ve olmayan faaliyetlere göre daha az ertelemeleriyle (Ferrari ve Scher, 2000) açıklanabilir. Ancak okul başarılarından memnun olmayan ve genel not ortalaması düşük olan öğrenciler daha fazla akademik erteleme davranışı göstermektedir (Çakıcı, 2003).

Dolayısıyla, üniversite öğrencilerinin hem akademik davranışları hususunda, kendi eğitimleri kadar başkalarına model teşkil etme gibi bir misyonlarının mevcut olması yanında, akademik erteleme davranışlarının internet bağımlılık düzeyleri açısından 
nasıl açıklandığının hem kendi eğitimleri açısından hem de diğer öğrencileri negatif akademik ertelemeye teşvik etme açısından sahip oldukları bilinç düzeyinin incelenmesi amaçlanmıştır.

\section{Yöntem}

\section{Araştırmanın Türü}

Bu çalışma, Sivas il merkezinde yer alan Cumhuriyet Üniversitesi Sağlık Bilimleri Fakültesi, Sağlık Hizmetleri Yüksekokulu sağlık yönetimi bölümünde okuyan üniversite öğrencilerinin internet bağımlılık düzeylerinin akademik ertelemeleri üzerindeki etkisinin ölçülmesi ve internet bağımlılık düzeyleriyle akademik ertelemenin öğrencilerin sosyodemografik özelliklerine göre farklılaşıp farklılaşmadığını ortaya koymak amacıyla tanımlayıcı ve kesitsel olarak planlanmış ve yapılmıştır.

\section{Araştırmanın Yeri ve Zamanı}

Araştırma, Mayıs - Haziran 2018 tarihleri arasında Sivas Cumhuriyet Üniversitesi Sağlık Bilimleri Fakültesi, Sağlık Hizmetleri Yüksekokulu sağlık yönetimi bölümünde yürütülmüştür.

\section{Araştırmanın Evren ve Örneklemi}

Araştırmanın evrenini; 2017-2018 eğitim-öğretim yılında, Sivas Cumhuriyet Üniversitesi Sağlık Bilimleri Fakültesi, Sağlık Hizmetleri Yüksekokulu sağlık yönetimi bölümünde okumakta olan toplam 222 üniversite öğrencisi oluşturmaktadır. Bu öğrencilerin 49’u 4'üncü, 55’i 3'üncü, 55’i 2'inci ve 63'ü 1'inci sınıfta olup, evrenin tamamına (\%100) ulaşılmıştır.

\section{Araştırmada Kullanılan Veri Toplama Araçları}

Veri toplama aracı olarak üniversite öğrencilerinin tanıtıcı özelliklerini belirlemeye yönelik 6 sorudan oluşan soru formu, Young (1996) tarafından geliştirilmiş 20 sorudan oluşan “İnternet Bağımlılığı Ölçeği (İBÖ)” ve Çakıcı (2003) tarafindan geliştirilen 19 sorudan oluşan “Akademik Erteleme Ölçeği (AEÖ)” kullanılmıştır.

İnternet Bağımlılığı Ölçeği (İBÖ): Young tarafından, DSM-IV’ün Patolojik Kumar Oynama kriterlerinden uyarlanarak oluşturulmuş 20 soru içeren bir ölçektir (Young, 1996). İnternet Bağımlılık Merkezi'nin http://www.netaddiction.com adresinden ulaşılabilen bu test kişinin kendini değerlendirdiği bir ölçektir. Türkçe uyarlaması 2001 yılında yapılmıştır (Bayraktar, 2001). Bayraktar'ın çalışmasında bu ölçeğin Cronbach Alpha iç tutarlık katsayısı .91, Spearman - Brown değeri .87 olarak saptanmış ve ölçeğin geçerli ve güvenilir olduğunu 
belirlemiştir. Likert tip olan bu ölçekte 'Nadiren', 'Bazen', 'Sıklıkla', 'Çoğu zaman' veya 'Her zaman' seçenekler vardır ve bu seçeneklere sırasıyla 1, 2, 3, 4 ve 5 puan verilmiştir. Ölçekten toplam 80 veya üzeri puan almak işlevsellikte ciddi bozulma göstergesi olarak kabul edilmekte ve bu kişiler internet bağımlısı olarak tariflenmektedir. 50-79 puan aralığında olanlar gündelik yaşamlarında internetle ilgili bir takım problemler yaşayan sınırda semptomatik olan grup olarak tariflenmektedir. 49 veya altında puan alanlar ise hayatında internet kullanımına bağlı herhangi problem yaşamayan normal internet kullanıcısı olarak tariflenmektedir.

Akademik Erteleme Ölçeği (AEÖ): Öğrencilerin akademik erteleme davranışlarını belirlemek amacıyla, Çakıcı (2003) tarafından geliştirilen "Akademik Erteleme Ölçeği” kullanılmıştır. Akademik Erteleme Ölçeği, öğrencilerin öğrenim yaşantılarında yapmakla sorumlu oldukları ders çalışma, sınavlara hazırlanma, proje hazırlama gibi görevleri içeren 19 ifadeden oluşmaktadır. Bu ifadelerin 12'si olumsuz, 7’si (1, 4, 7, 9, 11, 13, 17) olumludur. Bu ölçek beş basamaklı likert tipinde derecelendirilmektedir. $\mathrm{Bu}$ ifadeler "beni hiç yansıtmıyor","beni çok az yansitıyor”, "beni biraz yansıtıyor”, "beni çoğunlukla yansitıyor" "beni tamamen yansıtıyor" biçimindedir. Ölçekte akademik erteleme davranışı içeren bir ifadeye "beni hiç yansıtmıyor" diyenler 1, "beni tamamen yansıtıyor" diyenler 5 puan alacak biçimde tek yönlü puanlanmaktadır. Ölçekten alınabilecek en yüksek puan 95, en düşük puan 19'dur. Ölçekten alınan yüksek puanlar, öğrencilerin akademik konularda erteleme davranışlarının yüksek olduğunu göstermektedir (Çakıcı, 2003) İki faktörlü olan akademik erteleme ölçeğinde birinci faktör "erteleme", ikinci faktör ise "düzenli ders çalışma alışkanlığıdır.

Ölçeğin birinci faktörünün döndürme öncesi açıkladığı varyansın \%37,350 olması, döndürmeler sonrası açıkladığı varyansın da \%41,884 olması ölçeğin tek boyutlu olarak da kullanılabileceğine işaret etmektedir.

Bu araştırmada Akademik Erteleme Ölçeği tek boyutlu olarak kullanılmıştır. Akademik erteleme ölçeğinin Cronbach Alpha güvenirlik katsayısı .92 olarak bulunmuştur. Ölçeğin birinci faktörü için hesaplanan Cronbach Alpha katsayısı .89 ve ikinci faktörü için hesaplanan Cronbach alfa katsayısı .84'dür. Spearman Brown iki yarım test güvenirliği, on maddelik birinci yarım test için .87 , dokuz maddelik ikinci yarım test için .86 olmak üzere toplam .85 olarak hesaplanmıştır. Akademik Erteleme Ölçeğinin 65 lise öğrencisine on yedi gün ara ile uygulanmasından hesaplanan test-tekrar test korelasyon katsayısı .89 olarak bulunmuştur. Ölçeğin test tekrar test güvenirlik katsayısı birinci faktör için .80, ikinci faktör için .82 olarak 
hesaplanmıştır. Akademik Erteleme Ölçeğinin yapılan geçerlik ve güvenirlik çalışmaları geçerlik ve güvenirlik kriterlerini karşıladığını göstermektedir (Çakıcı, 2003).

\section{Verilerin İstatistiksel Değerlendirilmesi}

Verilerin istatistiksel analizi, bilgisayarda Statistical Package For Social Sciences (SPSS) 17.0 paket programı kullanılarak yapıldı. Anket uygulaması ile elde edilen verilerin çözümlenebilmesi için ilk olarak bu verilerin frekans(f) ve yüzde(\%) dağılımları bulundu. İBÖ ve AEÖ puanlarının normal dağılıma uygunluğu Tek Örneklem Kolmogorov Smirnov ve Shapiro-Wilk Testleri ile incelendi. İki grup arasında İBÖ ve AEÖ puanları açısından fark olup olmadığını belirlemek için “t-testi”, ikiden fazla grupta farklılığı araştırmak için ise “Tek Yönlü ANOVA” testi uygulandı. ANOVA testi sonrası Levene's testi ile grup dağılımlarının homojenliği kontrol edilerek değişkenlere göre hangi gruplar arasında farklılaştığını belirlemek üzere Post-Hoc Scheffe ve LSD testleri yapılıp, $\mathrm{p}<0.05$ düzeyi anlamlı olarak kabul edildi. Ölçekler arasındaki ilişkiyi belirlemeye yönelik pearson korelasyon, internet bağımlılığının akademik erteleme üzerindeki etkisinin test edilmesine yönelik ise regresyon analizi uygulanmıştır.

\section{Bulgular}

Araştırmanın bu bölümünde ölçme araçlarından elde edilen verilerin analizi sonucunda ortaya çıkan bulgular ve yorumlar sunulmuştur.

Araştırma kapsamındaki üniversite öğrencilerinin kişisel özellikleri Tablo 1'de verilmiştir.

Tablo 1: Katılımcıların Sosyo Demografik Özellikleri ( $n=222)$

\begin{tabular}{lll}
\hline Değişkenler & Sayı & \% \\
\hline Cinsiyet & 148 & 66,7 \\
Kadın & 74 & 33,3 \\
Erkek & & \\
\hline Yaş & 46 & 20,7 \\
19 ve altı & 40 & 18,0 \\
20 & 51 & 23,0 \\
21 & 43 & 19,4 \\
22 & 42 & 18,9 \\
23 ve üzeri & & \\
\hline Sınıf & 63 & 28,4 \\
1 & 55 & 24,8 \\
2 & 55 & 24,8 \\
3 & 49 & 22,1 \\
4 & & \\
\hline Öğrenim Türü & 110 & 49,5 \\
Birinci Öğrenim & 112 & 50,5 \\
İkinci Öğrenim & &
\end{tabular}

GANO* 


\begin{tabular}{lll} 
2,00 ve alt1 & 20 & 9,0 \\
$2,01-2,50$ & 55 & 24,8 \\
$2,51-3,00$ & 84 & 37,8 \\
$3,01-3,50$ & 49 & 22,1 \\
$3,51-4,00$ & 14 & 6,3 \\
\hline Alttan Ders alma Durumu & & \\
Evet & 153 & 68,9 \\
Hayir & 69 & 31,1 \\
*GNO: Genel Akademik Not Ortalamast &
\end{tabular}

Araştırmaya katılan kişilerin demografik dağılımları incelendiğinde; \%66,7'si kadın, \%33,3’ü erkek, \%20,7'si 19 yaş altı, \%18'i 20, \%23’ü 21, \%19,4’ü 22, \%18,9’u 23 yaş ve üzeri olarak belirlenmiştir. Katılımcıların \%28,4’ü 1’inci sınıf, \%24,8’i 2’nci sınıf, \%24,8’i 3’üncü sınıf, \%22,1’i 4'üncü sınıftır. \%49,5’i birinci öğretim, \%50,5’i ikinci öğretimde eğitim görmektedir. Genel akademik not ortalama dağılımları (GANO) incelendiğinde \%9'u 2,00 ve alt1, \%24,8’i 2,01-2,50, \%37,8’i 2,51-3,00, \%22,1’i 3,01-3,50, \%6,3’ü 3,51-4,00 aralı̆̆ındadır. \%68,9’u alttan ders alırken, \%31,1'inin alttan dersi bulunmamaktadır (Tablo 1).

İnternet bağımlılık düzeylerinin ve akademik erteleme ölçeklerinin normal dağılım testi sonuçları Tablo 2'de verilmiştir.

Tablo 2: İnternet Bağımlılık Düzeylerinin ve Akademik Erteleme Ölçeklerinin Normal Dağılım Testi Sonuçları

\begin{tabular}{llrrrrrr}
\hline & & \multicolumn{3}{c}{ Kolmogorov-Smirnov } & \multicolumn{3}{c}{ Shapiro-Wilk } \\
& İnternet Bağımlılık Ölçeği & Statistic & \multicolumn{1}{c}{ df } & \multicolumn{1}{c}{ Sig. } & Statistic & \multicolumn{1}{c}{ df } & \multicolumn{1}{c}{ Sig. } \\
\hline Akademik & Bağımlı Olmayan &, 067 & 114 &, $200^{*}$ &, 991 & 114 &, 629 \\
Erteleme Ölçeği & Riskli Kullanıc1 &, 084 & 101 &, 073 &, 979 & 101 &, 114 \\
& İnternet Bağımlısı &, 248 & 7 &, $200^{*}$ &, 943 & 7 &, 667 \\
\hline
\end{tabular}

*. This is a lower bound of the true significance.

a. Lilliefors Significance Correction

Yapılan normal dağılım analizi sonucunda ölçeklerin normal dağıldığı tespit edilmiştir $(\mathrm{p}>0,05)$. Analizlere parametrik testlerle devam edilmiştir.

\section{Akademik Erteleme Ölçeğine İlișkin Analizler}

Akademik erteleme ölçeğine ait betimleyici istatistikler Tablo 3'de sunulmuştur.

Tablo 3: Akademik Erteleme Ölçeğine Ait Betimleyici İstatistikler

\begin{tabular}{lcc}
\hline & $\bar{X}$ & s.s. \\
\hline Akademik Erteleme & 2,98 &, 75 \\
\hline
\end{tabular}

Tablo 3'de akademik erteleme ölçeği için tanımlayıcı istatistik sonuçları verilmiştir.

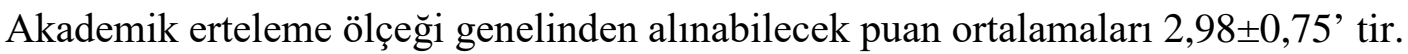

Akademik erteleme ölçeğinin cinsiyete göre farklılaşma durumuna ait bağımsız örneklem t-testi sonuçları Tablo 4'de sunulmuştur. 
Tablo 4: Akademik Erteleme Ölçeğinin Cinsiyete Göre Farklılaşma Durumuna Ait Bağımsız Örneklem T-Testi Sonuçları

\begin{tabular}{|c|c|c|c|c|c|c|c|c|}
\hline & \multirow[b]{2}{*}{ Cinsiyet } & \multirow{2}{*}{$\mathbf{n}$} & \multirow{2}{*}{$\bar{x}$} & \multirow{2}{*}{ S.S. } & \multicolumn{2}{|c|}{ Levene Testi } & \multirow[b]{2}{*}{ t } & \multirow[b]{2}{*}{$\mathbf{P}$} \\
\hline & & & & & $\mathbf{F}$ & $\mathbf{p}$ & & \\
\hline \multirow{2}{*}{$\begin{array}{l}\text { Akademik } \\
\text { Erteleme }\end{array}$} & Kadın & 148 & 2,83 & ,82 & \multirow{2}{*}{0,721} & \multirow{2}{*}{0,397} & \multirow{2}{*}{2,075} & \multirow{2}{*}{$0,039 *$} \\
\hline & Erkek & 74 & 3,05 & ,70 & & & & \\
\hline
\end{tabular}

${ }^{*} \mathbf{p}<\mathbf{0 , 0 5}$

Ho: Katılımcıların akademik erteleme ölçeğine ait görüşlerinin cinsiyete göre farklılıkları istatistiksel olarak anlamlı değildir.

H1: Katılımcıların akademik erteleme ölçeğine ait görüşlerinin cinsiyete göre farklılıkları istatistiksel olarak anlamlıdır.

Araştırmaya katılanların akademik erteleme ölçeğine ait algıların cinsiyete göre farklılığın istatistiksel olarak anlamlı olup olmamasını test etmek için yapılan bağımsız örneklem t testi sonucuna göre, katılımcıların akademik erteleme algılarının cinsiyete göre farklılığın istatistiksel olarak \%95 güven seviyesinde anlamlı olduğu belirlenmiştir $(t=2,075$; $\mathrm{p}<0,05)$. Erkeklerin $(\bar{x}=\mathbf{3 , 0 8})$ akademik erteleme algıları kadınlara $(\bar{x}=\mathbf{2 , 8 3})$ göre daha yüksektir.

Akademik erteleme ölçeğinin öğrenim türüne göre farklılaşma durumuna ait bağımsız örneklem t-testi sonuçları Tablo 5'de sunulmuştur.

Tablo 5: Akademik Erteleme Ölçeğinin Öğrenim Türüne Göre Farklılaşma Durumuna Ait Bağımsız Örneklem T-Testi Sonuçları

\begin{tabular}{|c|c|c|c|c|c|c|c|c|}
\hline & \multirow{2}{*}{ Öğrenim Türü } & \multirow{2}{*}{$\mathbf{n}$} & \multirow{2}{*}{$\bar{x}$} & \multirow{2}{*}{ S.S. } & \multicolumn{2}{|c|}{ Levene Testi } & \multirow[b]{2}{*}{$\mathbf{t}$} & \multirow{2}{*}{$\mathbf{P}$} \\
\hline & & & & & $\mathbf{F}$ & $\mathbf{p}$ & & \\
\hline \multirow{2}{*}{$\begin{array}{l}\text { Akademik } \\
\text { Erteleme }\end{array}$} & Birinci Öğretim & 110 & 3,04 & ,69 & \multirow{2}{*}{3,161} & \multirow{2}{*}{,077 } & \multirow{2}{*}{1,272} & \multirow{2}{*}{ 205 } \\
\hline & İkinci Öğretim & 112 & 2,91 & 80 & & & & \\
\hline
\end{tabular}

Ho: Katılımcıların akademik erteleme ölçeğine ait görüşlerinin öğrenim durumuna göre farklılıkları istatistiksel olarak anlamlı değildir.

H1: Katılımcıların akademik erteleme ölçeğine ait görüşlerinin öğrenim durumuna göre farklılıkları istatistiksel olarak anlamlıdır.

Araştırmaya katılanların akademik erteleme ölçeğine ait algıların öğrenim durumuna göre farklılığın istatistiksel olarak anlamlı olup olmamasını test etmek için yapılan bağımsız örneklem t testi sonucuna göre, katılımcıların akademik erteleme algılarının öğrenim durumuna göre farklılığ istatistiksel olarak \%95 güven seviyesinde anlamlı olmadığ belirlenmiştir $(\mathrm{p}>0,05)$. 
Akademik erteleme ölçeğinin alttan ders alma durumuna göre farklılaşma durumuna ait bağımsız örneklem t-testi sonuçları Tablo 6'da sunulmuştur.

Tablo 6: Akademik Erteleme Ölçeğinin Alttan Ders Alma Durumuna Göre Farklılaşma Durumuna Ait Bağımsız Örneklem T-Testi Sonuçları

\begin{tabular}{|c|c|c|c|c|c|c|c|c|}
\hline & \multirow{2}{*}{$\begin{array}{l}\text { Alttan Ders } \\
\text { Alma Durumu }\end{array}$} & \multirow[b]{2}{*}{$\mathbf{n}$} & \multirow[b]{2}{*}{$\bar{x}$} & \multirow[b]{2}{*}{ S.s. } & \multicolumn{2}{|c|}{ Levene Testi } & \multirow[b]{2}{*}{$\mathbf{t}$} & \multirow[b]{2}{*}{$\mathbf{P}$} \\
\hline & & & & & $\mathbf{F}$ & $\mathbf{p}$ & & \\
\hline \multirow{2}{*}{$\begin{array}{l}\text { Akademik } \\
\text { Erteleme }\end{array}$} & Evet & 153 & 2,89 & ,74 & \multirow{2}{*}{,565 } & \multirow{2}{*}{,453 } & \multirow{2}{*}{$-2,556$} & \multirow{2}{*}{,011* } \\
\hline & Hayır & 69 & 3,17 & ,74 & & & & \\
\hline
\end{tabular}

${ }^{*} \mathbf{p}<\mathbf{0 , 0 5}$

Ho: Katılımcıların akademik erteleme ölçeğine ait görüşlerinin alttan ders alma durumuna göre farklılıkları istatistiksel olarak anlamlı değildir.

$\mathbf{H}_{1}$ : Katılımcıların akademik erteleme ölçeğine ait görüşlerinin alttan ders alma durumuna göre farklılıkları istatistiksel olarak anlamlıdır.

Araştırmaya katılanların akademik erteleme ölçeğine ait algıların alttan ders alma durumuna göre farklılığın istatistiksel olarak anlamlı olup olmamasını test etmek için yapılan bağımsız örneklem t testi sonucuna göre, katılımcıların akademik erteleme algılarının alttan ders alma durumuna göre farklılığı istatistiksel olarak \%95 güven seviyesinde anlamlı olduğu belirlenmiştir $(\mathrm{t}=-2,556 ; \mathrm{p}<0,05)$. Alttan ders alanların $(\bar{x}=\mathbf{2 , 8 9})$ akademik erteleme algıları alttan ders almayanlara $(\bar{x}=3,17)$ göre daha düşüktür.

Akademik erteleme ölçeğinin yaş gruplarına göre farklılaşma durumuna ait tek yönlü ANOVA testi sonuçları Tablo 7'de sunulmuştur.

Tablo 7: Akademik Erteleme Ölçeğinin Yaş Gruplarına Göre Farklılaşma Durumuna Ait Tek Yönlü ANOVA Testi Sonuçları

\begin{tabular}{|c|c|c|c|c|c|c|}
\hline & Yaş & $\mathbf{n}$ & $\bar{x}$ & s.s. & $\mathbf{F}$ & $\mathbf{p}$ \\
\hline \multirow[t]{5}{*}{ Akademik Erteleme } & 19 ve altı & 46 & 3,08 & ,70 & \multirow{5}{*}{1,686} & \multirow{5}{*}{ 154 } \\
\hline & 20 & 40 & 2,78 & 80 & & \\
\hline & 21 & 51 & 3,06 & ,77 & & \\
\hline & 22 & 43 & 3,10 & ,69 & & \\
\hline & $23+$ & 42 & 2,83 & ,75 & & \\
\hline
\end{tabular}

Ho: Katılımcıların akademik erteleme ölçeğine ait görüşlerinin yaşa göre farklılıkları istatistiksel olarak anlamlı değildir.

H1: Katılımcıların akademik erteleme ölçeğine ait görüşlerinin yaşa göre farklılıkları istatistiksel olarak anlamlıdir. 
Araştırmaya katılanların akademik erteleme ölçeğine ait algıların yaşa göre farklılığın istatistiksel olarak anlamlı olup olmamasını test etmek için yapılan tek yönlü ANOVA testi sonuçlarına göre, akademik erteleme algılarının yaş gruplarına göre istatistiksel olarak \%95 güven seviyesinde anlamlı olmadığı belirlenmiştir $(\mathrm{p}>0,05)$.

Akademik erteleme ölçeğinin sınıf değişkenine göre farklılaşma durumuna ait tek yönlü ANOVA testi sonuçları Tablo 8'de sunulmuştur.

Tablo 8: Akademik Erteleme Ölçeğinin Sınıf Değişkenine Göre Farklılaşma Durumuna Ait Tek Yönlü ANOVA Testi Sonuçları

\begin{tabular}{lllllll}
\hline & Sinif & $\mathbf{n}$ & $\bar{x}$ & s.s. & F & p \\
\hline Akademik & 1 & 63 & 2,99 &, 76 \\
Erteleme & 2 & 55 & 2,99 &, 79 & \\
\cline { 2 - 5 } & 3 & 55 & 2,92 &, 71 & \\
\cline { 2 - 5 } & 4 & 49 & 3,02 &, 74 & \\
\hline
\end{tabular}

Ho: Katılımcıların akademik erteleme ölçeğine ait görüşlerinin sınıfa göre farklılıkları istatistiksel olarak anlamlı değildir.

$\mathbf{H}_{1}$ : Katılımcıların akademik erteleme ölçeğine ait görüşlerinin sınıfa göre farklılıkları istatistiksel olarak anlamlıdır.

Araştırmaya katılanların akademik erteleme ölçeğine ait algıların sınıfa göre farklılığın istatistiksel olarak anlamlı olup olmamasını test etmek için yapılan tek yönlü anova testi sonuçlarına göre, akademik erteleme algılarının sınıf gruplarına göre istatistiksel olarak \%95 güven seviyesinde anlamlı olmadığg belirlenmiştir $(\mathrm{p}>0,05)$.

Akademik erteleme ölçeğinin GANO değişkenine göre farklılaşma durumuna ait tek yönlü ANOVA testi sonuçları Tablo 9'da sunulmuştur.

Tablo 9: Akademik Erteleme Ölçeğinin GANO Değişkenine Göre Farklılaşma Durumuna Ait Tek Yönlü ANOVA Testi Sonuçları

\begin{tabular}{|c|c|c|c|c|c|c|c|}
\hline & GANO & $\mathbf{n}$ & $\bar{x}$ & s.s. & $\mathbf{F}$ & $\mathbf{p}$ & Scheffe \\
\hline \multirow{5}{*}{$\begin{array}{l}\text { Akademik } \\
\text { Erteleme }\end{array}$} & 2,00 ve altt ${ }^{(1)}$ & 20 & 2,73 & ,59 & \multirow{5}{*}{7,089} & \multirow{5}{*}{, $000 *$} & \multirow{5}{*}{$\begin{array}{l}(1-5) \\
(2-5) \\
(2-4)\end{array}$} \\
\hline & $2,01-2,50^{(2)}$ & 55 & 2,72 & ,78 & & & \\
\hline & $2,51-3,00^{(3)}$ & 84 & 2,92 & ,64 & & & \\
\hline & $3,01-3,50^{(4)}$ & 49 & 3,31 & ,77 & & & \\
\hline & $3,51-4,00^{(5)}$ & 14 & 3,52 & ,73 & & & \\
\hline
\end{tabular}


Ho: Katılımcıların akademik erteleme ölçeğine ait görüşlerinin GANO değişkenine göre farklılıkları istatistiksel olarak anlamlı değildir.

H1: Katılımcıların akademik erteleme ölçeğine ait görüşlerinin GANO değişkenine göre farklılıkları istatistiksel olarak anlamlıdır.

Araştırmaya katılanların akademik erteleme ölçeğine ait algıların GANO değişkenine göre farklılığın istatistiksel olarak anlamlı olup olmamasını test etmek için yapılan tek yönlü ANOVA testi sonuçlarına göre, akademik erteleme algılarının GANO değişkeni gruplarına göre istatistiksel olarak \%95 güven seviyesinde anlamlı olduğu belirlenmiştir $(F=7,089$; $\mathrm{p}<0,05)$. Katılımcıların akademik erteleme algılarına ait varyansların homojenlik testi sonucunda varyanslar homojen bulunduğundan $(\mathrm{p}=0,355 ; \mathrm{p}<0,05)$ farklılaşmanın kaynağının belirlenmesi amacıyla post hoc testlerinden Scheffe testi kullanılmıştır. Scheffe testi sonucunda GANO puanı 2,00 ve altı olanların $(\bar{x}=\mathbf{2 , 7 3})$ akademik erteleme algiları 3,51-4,00 ( $\bar{x}=\mathbf{3 , 5 2})$ olanlara göre daha düşüktür. 2,01-2,50 olanların $(\bar{x}=2,72)$ akademik erteleme algıları 3,01-3,50 $(\bar{x}=3,31), 3,51-4,00(\bar{x}=3,52)$ olanlara göre daha düşüktür.

\section{İnternet Bağımlılı̆ğ Ölçeğine İliş̧kin Analizler}

İnternet bağımlılığg ölçeğine ait betimleyici istatistikler Tablo 10'da sunulmuştur.

Tablo 10: İnternet Bağımlılı̆̆ı Ölçeğine Ait Betimleyici İstatistikler

\begin{tabular}{lcc}
\hline & $\bar{X}$ & s.s. \\
\hline İnternet Bağımlılı̆̆1 & 48,93 & 15,63 \\
\hline
\end{tabular}

Tablo 10’da internet bağımlılığı ölçeği için tanımlayıcı istatistik sonuçları verilmiştir.

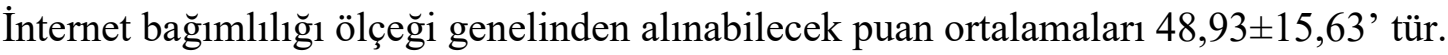

Katılımcıların internet bağımlılığı düzeyleri dağılımları Tablo 11'de sunulmuştur.

Tablo 11: Katılımcıların İnternet Bağımlılığı Düzeyleri Dağılımları

\begin{tabular}{lcc}
\hline Düzeyler & Sayı & \% \\
\hline Bağımlı Olmayan & 114 & 51,4 \\
Riskli Kullanıcı & 101 & 45,5 \\
İnternet Bağımlısı & 7 & 3,2 \\
\hline Toplam & $\mathbf{2 2 2}$ & $\mathbf{1 0 0 , 0}$ \\
\hline
\end{tabular}

Araştırma kapsamındaki kişilerin \%51,4’ü internet bağımlısı değil, \%45,5’i riskli kullanıc1, \%3,2'si ise internet bağımlısı olarak belirlenmiştir. 
İnternet bağımlılığı ölçeğinin cinsiyete göre farklılaşma durumuna ait bağımsız örneklem t-testi sonuçları Tablo 12'de sunulmuştur.

Tablo 12: İnternet Bağımlılı̆̆ı Ölçeğinin Cinsiyete Göre Farklılaşma Durumuna Ait Bağımsız Örneklem T-Testi Sonuçları

\begin{tabular}{|c|c|c|c|c|c|c|c|c|}
\hline & \multirow[b]{2}{*}{ Cinsiyet } & \multirow[b]{2}{*}{$\mathbf{n}$} & \multirow{2}{*}{$\bar{x}$} & \multirow[b]{2}{*}{ s.s. } & \multicolumn{2}{|c|}{ Levene Testi } & \multirow[b]{2}{*}{$\mathbf{t}$} & \multirow{2}{*}{$\mathbf{P}$} \\
\hline & & & & & $\mathbf{F}$ & $\mathbf{p}$ & & \\
\hline \multirow{2}{*}{$\begin{array}{l}\text { İnternet } \\
\text { Bağımlılığı }\end{array}$} & Kadın & 148 & 45,52 & 14,96 & \multirow{2}{*}{0,369} & \multirow{2}{*}{0,544} & \multirow{2}{*}{$-4,832$} & \multirow{2}{*}{$0,000 *$} \\
\hline & Erkek & 74 & 55,77 & 14,77 & & & & \\
\hline
\end{tabular}
* $\mathbf{p}<\mathbf{0 , 0 5}$

Ho: Katılımcıların internet bağımlılığı ölçeğine ait görüşlerinin cinsiyete göre farklılıkları istatistiksel olarak anlamlı değildir.

H1: Katılımcıların internet bağımlılığı ölçeğine ait görüşlerinin cinsiyete göre farklılıkları istatistiksel olarak anlamlıdır.

Araştırmaya katılanların internet bağımlılı̆̆ı ölçeğine ait algıların cinsiyete göre farklılığın istatistiksel olarak anlamlı olup olmamasını test etmek için yapılan bağımsız örneklem t testi sonucuna göre, katılımcıların internet bağımlılığı algılarının cinsiyete göre farklılığı istatistiksel olarak \%95 güven seviyesinde anlamlı olduğu belirlenmiştir $(\mathrm{t}=-4,832$; $\mathrm{p}<0,05)$. Kadınların $(\bar{x}=\mathbf{4 5}, 52)$ internet bağımlılığ 1 algıları erkeklere $(\bar{x}=55,77)$ göre daha düşüktür.

İnternet bağımlılığı ölçeğinin öğrenim türüne göre farklılaşma durumuna ait bağımsız örneklem t-testi sonuçları Tablo 13'de sunulmuştur.

Tablo 13: İnternet Bağımlılı̆ğ Ölçeğinin Öğrenim Türüne Göre Farklılaşma Durumuna Ait Bağımsız Örneklem T-Testi Sonuçları

\begin{tabular}{|c|c|c|c|c|c|c|c|c|}
\hline & \multirow{2}{*}{ Öğrenim Türü } & \multirow{2}{*}{$\mathbf{n}$} & \multirow{2}{*}{$\bar{x}$} & \multirow[b]{2}{*}{ S.S. } & \multicolumn{2}{|c|}{ Levene Testi } & \multirow[b]{2}{*}{$\mathbf{t}$} & \multirow[b]{2}{*}{$\mathbf{P}$} \\
\hline & & & & & $\mathbf{F}$ & $\mathbf{p}$ & & \\
\hline \multirow{2}{*}{$\begin{array}{l}\text { Internet } \\
\text { Bağımlılığı }\end{array}$} & Birinci Öğretim & 110 & 48,20 & 15,57 & \multirow{2}{*}{0,167} & \multirow{2}{*}{,683 } & \multirow{2}{*}{$-0,695$} & \multirow{2}{*}{,488 } \\
\hline & İkinci Öğretim & 112 & 49,66 & 15,72 & & & & \\
\hline
\end{tabular}

Ho: Katılımcıların internet bağımlılı̆̆ ölçeğine ait görüşlerinin öğrenim durumuna göre farklılıkları istatistiksel olarak anlamlı değildir.

H1: Katılımcıların internet bağımlılığı ölçeğine ait görüşlerinin öğrenim durumuna göre farklılıkları istatistiksel olarak anlamlıdır.

Araştırmaya katılanların internet bağımlılığı ölçeğine ait algıların öğrenim durumuna göre farklılı̆̆ın istatistiksel olarak anlamlı olup olmamasını test etmek için yapılan bağımsız örneklem $\mathrm{t}$ testi sonucuna göre, katılımcıların internet bağımlılı̆̆ 
durumuna göre farklılı̆̆ istatistiksel olarak \%95 güven seviyesinde anlamlı olmadığ belirlenmiştir ( $p>0,05)$.

İnternet bağımlılığı ölçeğinin alttan ders alma durumuna göre farklılaşma durumuna ait bağımsız örneklem t-testi sonuçları Tablo 14'de sunulmuştur.

Tablo 14: İnternet Bağımlılı̆̆ı Ölçeğinin Alttan Ders Alma Durumuna Göre Farklılaşma Durumuna Ait Bağımsız Örneklem T-Testi Sonuçları

\begin{tabular}{|c|c|c|c|c|c|c|c|c|}
\hline & \multirow{2}{*}{$\begin{array}{l}\text { Alttan } \\
\text { Ders Alma } \\
\text { Durumu }\end{array}$} & \multirow[b]{2}{*}{$\mathbf{n}$} & \multirow[b]{2}{*}{$\bar{x}$} & \multirow[b]{2}{*}{ s.s. } & \multicolumn{2}{|c|}{ Levene Testi } & \multirow[b]{2}{*}{$\mathbf{t}$} & \multirow[b]{2}{*}{$\mathbf{P}$} \\
\hline & & & & & $\bar{F}$ & $\mathbf{p}$ & & \\
\hline \multirow{2}{*}{$\begin{array}{l}\text { Internet } \\
\text { Bağımlılığı }\end{array}$} & Evet & 153 & 50,13 & 15,43 & \multirow{2}{*}{ 033, } & \multirow{2}{*}{ 855, } & \multirow{2}{*}{1,711} & \multirow{2}{*}{,089 } \\
\hline & Hayır & 69 & 46,27 & 15,84 & & & & \\
\hline
\end{tabular}

Ho: Katılımcıların internet bağımlılı̆̆ı ölçeğine ait görüşlerinin alttan ders alma durumuna göre farklılıkları istatistiksel olarak anlamlı değildir.

H1: Katılımcıların internet bağımlılığı ölçeğine ait görüşlerinin alttan ders alma durumuna göre farklılıkları istatistiksel olarak anlamlıdır.

Araştırmaya katılanların internet bağımlılığı ölçeğine ait algıların alttan ders alma durumuna göre farklılığın istatistiksel olarak anlamlı olup olmamasını test etmek için yapılan bağımsız örneklem t testi sonucuna göre, katılımcıların internet bağımlılığı algılarının alttan ders alma durumuna göre farklılığı istatistiksel olarak \%95 güven seviyesinde anlamlı olmadığ belirlenmiştir ( $p>0,05)$.

İnternet bağımlılı̆̆g ölçeğinin yaş gruplarına göre farklılaşma durumuna ait tek yönlü ANOVA testi sonuçları Tablo 15'de sunulmuştur.

Tablo 15: İnternet Bağımlılı̆̆ı Ölçeğinin Yaş Gruplarına Göre Farklılaşma Durumuna Ait Tek Yönlü ANOVA Testi Sonuçları

\begin{tabular}{|c|c|c|c|c|c|c|c|}
\hline & Yaş & $\mathbf{n}$ & $\bar{x}$ & s.s. & $\mathbf{F}$ & $\mathbf{p}$ & LSD \\
\hline \multirow{5}{*}{$\begin{array}{l}\text { İnternet } \\
\text { Bağımlılığı }\end{array}$} & 19 ve altı ${ }^{(1)}$ & 46 & 51,39 & 15,66 & \multirow{5}{*}{2,688} & \multirow{5}{*}{,032* } & \multirow{5}{*}{$\begin{array}{l}(1-3) \\
(2-5) \\
(3-5)\end{array}$} \\
\hline & $20^{(2)}$ & 40 & 46,12 & 15,39 & & & \\
\hline & $21^{(3)}$ & 51 & 45,03 & 15,11 & & & \\
\hline & $22^{(4)}$ & 43 & 48,39 & 14,62 & & & \\
\hline & $23+(5)$ & 42 & 54,21 & 16,22 & & & \\
\hline
\end{tabular}

Ho: Katılımcıların internet bağımlılı̆̆ı ölçeğine ait görüşlerinin yaşa göre farklılıkları istatistiksel olarak anlamlı değildir.

H1: Katılımcıların internet bağımlılı̆̆ı ölçeğine ait görüşlerinin yaşa göre farklılıkları istatistiksel olarak anlamlıdır. 
Araştırmaya katılanların internet bağımlılı̆̆ı ölçeğine ait algıların yaşa göre farklılığın istatistiksel olarak anlamlı olup olmamasını test etmek için yapılan tek yönlü ANOVA testi sonuçlarına göre, internet bağımlılı̆gı algılarının yaş gruplarına göre istatistiksel olarak \%95 güven seviyesinde anlamlı olduğu belirlenmiştir $(F=2,688 ; \mathrm{p}<0,05)$. Katılımcıların internet bağımlılığı akademik erteleme algılarına ait varyansların homojenlik testi sonucunda varyanslar homojen bulunduğundan $(p=0,980 ; p<0,05)$ farklılaşmanın kaynağının belirlenmesi amacıyla post hoc testlerinden LSD testi kullanılmıştır. LSD testi sonucunda 19 yaş ve altı olanların $(\bar{x}=51,39)$ internet bağımlılığı algıları 21 yaşında $(\bar{x}=\mathbf{4 5 , 0 3 )}$ olanlara göre daha yüksektir. 23 yaş ve üzeri olanların $(\bar{x}=54,21)$ internet bağımlılı̆̆ı algıları $20(\bar{x}=\mathbf{4 6 , 1 2}), 21$ yaşında $(\bar{x}=\mathbf{4 5 , 0 3})$ olanlara göre daha yüksektir.

İnternet bağımlılığı ölçeğinin sınıf değişkenine göre farklılaşma durumuna ait tek yönlü ANOVA testi sonuçları Tablo 16' da sunulmuştur.

Tablo 16: İnternet Bağımlılığı Ölçeğinin Sınıf Değişkenine Göre Farklılaşma Durumuna Ait Tek Yönlü Anova Testi Sonuçları

\begin{tabular}{lcccccc}
\hline & Sinıf & $\mathbf{n}$ & $\bar{x}$ & s.s. & F & p \\
\hline Internet & 1 & 63 & 47,22 & 15,93 & & \\
Bağımlılığı & 2 & 55 & 46,16 & 16,04 & & \\
\cline { 2 - 5 } & 3 & 55 & 51,58 & 13,83 & & \multirow{2}{*}{160} \\
\cline { 2 - 5 } & 4 & 49 & 51,28 & 16,32 & & \\
\hline
\end{tabular}

Ho: Katılımcıların internet bağımlılığı ölçeğine ait görüşlerinin sınıfa göre farklılıkları istatistiksel olarak anlamlı değildir.

H1: Katılımcıların internet bağımlılığı ölçeğine ait görüşlerinin sınıfa göre farklılıkları istatistiksel olarak anlamlıdır.

Araştırmaya katılanların internet bağımlılı̆̆ı ölçeğine ait algıların sınıfa göre farklılığın istatistiksel olarak anlamlı olup olmamasını test etmek için yapılan tek yönlü ANOVA testi sonuçlarına göre, internet bağımlılığı algılarının sınıf gruplarına göre istatistiksel olarak \%95 güven seviyesinde anlamlı olmadığg belirlenmiştir $(\mathrm{p}>0,05)$.

İnternet bağımlılı̆̆ı ölçeğinin GANO değişkenine göre farklılaşma durumuna ait tek yönlü ANOVA testi sonuçları Tablo 17'de sunulmuştur.

Tablo 17: İnternet Bağımlılığı Ölçeğinin GANO Değişkenine Göre Farklılaşma Durumuna Ait Tek Yönlü ANOVA Testi Sonuçları

\begin{tabular}{lllllllc}
\hline & GANO & n & $\bar{x}$ & s.s. & F & p & Scheffe \\
\hline $\begin{array}{llllll}\text { Internet } \\
\text { Bağımlılı̆̆ }\end{array}$ & 2,00 ve altı ${ }^{(1)}$ & 20 & 51,00 & 12,98 & \multirow{2}{*}{4,678} & \multirow{2}{*}{$001^{*}$} & $(1-5)$ \\
\cline { 2 - 5 } & $2,01-2,50^{(2)}$ & 55 & 51,61 & 16,26 & & & $(2-5)$ \\
\hline
\end{tabular}




\begin{tabular}{llll}
$2,51-3,00^{(3)}$ & 84 & 49,69 & 15,18 \\
\hline $3,01-3,50^{(4)}$ & 49 & 48,46 & 15,19 \\
\hline $3,51-4,00^{(5)}$ & 14 & 32,57 & 12,48
\end{tabular}

*p<0,05

Ho: Katılımcıların internet bağımlılığı ölçeğine ait görüşlerinin GANO değişkenine göre farklılıkları istatistiksel olarak anlamlı değildir.

H1: Katılımcıların internet bağımlılı̆̆ı ölçeğine ait görüşlerinin GANO değişkenine göre farklılıkları istatistiksel olarak anlamlıdır.

Araştırmaya katılanların internet bağımlılığı ölçeğine ait algıların GANO değişkenine göre farklılığın istatistiksel olarak anlamlı olup olmamasını test etmek için yapılan tek yönlü ANOVA testi sonuçlarına göre, internet bağımlılığı algılarının GANO değişkeni gruplarına göre istatistiksel olarak \%95 güven seviyesinde anlamlı olduğu belirlenmiştir $(\mathrm{F}=4,678$; $\mathrm{p}<0,05)$. Katılımcıların internet bağımlılığı algılarına ait varyansların homojenlik testi sonucunda varyanslar homojen bulunduğundan $(p=0,472 ; p<0,05)$ farklılaşmanın kaynağının belirlenmesi amacıyla post hoc testlerinden Scheffe testi kullanılmıştır. Scheffe testi sonucunda GANO puanı 3,51-4,00 ( $\bar{x}=\mathbf{3 2 , 5 7 )}$ olanların internet bağımlılığı algıları 2,00 ve alt1 $(\bar{x}=\mathbf{5 1 , 0 0})$, 2,01-2,50 ( $\bar{x}=\mathbf{5 1 , 6 1}), 2,51-3,00(\bar{x}=\mathbf{4 9 , 6 9}), 3,01-3,50(\bar{x}=\mathbf{4 8 , 4 6})$ olanlara göre daha düşüktür.

Ölçekler arasındaki ilişkiyi belirlemeye yönelik pearson korelasyon analiz sonuçları Tablo 18'de sunulmuştur.

Tablo 18: Ölçekler Arasındaki İlişkiyi Belirlemeye Yönelik Pearson Korelasyon Analiz Sonuçları

\begin{tabular}{lcc}
\hline & Akademik Erteleme & $\begin{array}{c}\text { İnternet } \\
\text { Bağımlll } \breve{g ̆}_{1}\end{array}$ \\
\cline { 2 - 3 } Akademik Erteleme & 1 &,$- 382^{* *}$ \\
\hline \multirow{2}{*}{ İnternet Bağımlılığ } & \multicolumn{2}{c}{1} \\
\cline { 2 - 3 } & \\
\hline
\end{tabular}

Tablo 18’ deki; genel ölçekler arasındaki ilişki incelendiğinde; akademik erteleme ile internet bağımlılığı arasında negatif yönde düşük kuvvetli bir ilişki olduğu belirlenmiştir. $(\mathrm{p}<0.01, \mathrm{p}=0,000, \mathrm{r}=-0,382)$.

İnternet bağımlılığının akademik erteleme üzerindeki etkisine test edilmesine yönelik regresyon analizi sonuçları Tablo 19'da sunulmuştur.

Tablo 19: İnternet Bağımlılığının Akademik Erteleme Üzerindeki Etkisine Test Edilmesine Yönelik Regresyon Analizi Sonuçları 


\begin{tabular}{lccccccc}
\hline & $\mathbf{B}$ & $\mathbf{t}$ değeri & $\mathbf{P}$ değeri & $\mathbf{R}^{\mathbf{2}}$ & Düzeltilmiş $\mathbf{R}^{\mathbf{2}}$ & $\mathbf{F}$ & Anlamlılık F \\
\hline Sabit & 3,882 & 25,224 &, 000 & 0,146 & 0,142 & 37,604 & 0,000 \\
\cline { 1 - 4 } İnternet Bağımlıı̆̆ı & $-0,018$ & $-6,132$ &, 000 & & & & \\
\hline
\end{tabular}

Regresyon analizi sonuçları incelendiğinde: internet bağımlılığının akademik erteleme üzerinde anlamlı bir etkiye sahip olduğu görülmektedir. İnternet bağımlılığının akademik ertelemeyi (0,05 anlamlılık seviyesinde) \%14,2 oranında açıkladığı belirlenmiştir. Regresyon modeli aşağıdaki gibidir.

Akademik Erteleme=3,882-0,018* İnternet Bağımlılı̆̆

\section{Tartışma ve Sonuç}

Bu çalışma, Sivas il merkezinde yer alan Cumhuriyet Üniversitesi Sağlık Bilimleri Fakültesi, Sağlık Hizmetleri Yüksekokulu sağlık yönetimi bölümünde okuyan üniversite öğrencilerinin internet bağımlılık düzeylerinin akademik ertelemeleri üzerindeki etkisinin ölçülmesi ve internet bağımlılık düzeyleriyle akademik ertelemenin öğrencilerin sosyodemografik özelliklerine göre farklılaşıp farklılaşmadığını ortaya koymak amacıyla tanımlayıcı ve kesitsel olarak planlanmış ve yapılmıştır.

Araştırmaya katılan üniversite öğrencilerinin genel tanımlayıcı özelliklerine göre öğrencilerin \%66,7'si kadın, \%33,3'ü erkek, \%20,7'si 19 yaş altı, \%18'i 20, \%23'ü 21, \%19,4'ü 22, \%18,9'u 23 yaş ve üzeri olarak belirlenmiştir. Katılımcıların \%28,4'ü 1'inci sınıf, \%24,8'i 2'nci sınıf, \%24,8'i 3'üncü sınıf, \%22,1'i 4'üncü sınıftır. \%49,5'i birinci öğretim, \%50,5'i ikinci öğretimde eğitim görmektedir. Genel akademik not ortalama dağılımları (GANO) incelendiğinde \%9'u 2,00 ve alt1, \%24,8'i 2,01-2,50, \%37,8'i 2,51-3,00, \%22,1'i 3,01-3,50, \%6,3'ü 3,51-4,00 aralığındadır. \%68,9'u alttan ders alırken, \%31,1'inin alttan dersi bulunmamaktadir.

Akademik erteleme ölçeği genelinden alınabilecek puan ortalamaları 2,98 $\pm 0,75$ 'dir (Tablo 3). İnternet bağımlılı̆̆ı ölçeği genelinden alınabilecek puan ortalamaları ise

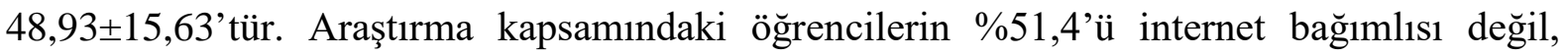
\%45,5'i riskli kullanıcı, \%3,2'si ise internet bağımlısı olarak belirlenmiştir. Genel ölçekler arasındaki ilişki incelendiğinde; akademik erteleme ile internet bağımlılığı arasında negatif yönde düşük kuvvetli bir ilişki olduğu belirlenmiştir ( $\mathrm{p}<0.01)$. Akdemir (2013) araştırmasında, öğrencilerin facebook tutumları ile akademik erteleme eğilimleri arasında \%50.1 düzeyinde bir korelasyon tespit etmiştir. Öğrencilerin Facebook davranışları arttıkça, akademik ertelemeleri 
de yükselmektedir. Paul, Baker ve Cochran (2012) gerçekleştirdikleri çalışmalarında, facebook hesabını sık sık kullanan öğrencilerin akademik erteleme puanlarının, nadiren kullanan öğrencilerden daha yüksek olduğunu ifade etmişlerdir. Regresyon analizi sonuçları incelendiğinde: internet bağımlılı̆̆ının akademik erteleme üzerinde anlamlı bir etkiye sahip olduğu görülmektedir. İnternet bağımlılığının akademik ertelemeyi $(0,05$ anlamlılık seviyesinde) \%14,2 oranında açıkladığg belirlenmiştir. Gürültü (2016) araştırmasında, sosyal medya bağımlılığı ve akademik erteleme arasında pozitif yönde anlamlı ilişki bulmuş ve sosyal medya bağımlılığının akademik erteleme davranışının yaklaşık \%19’unu açıkladığını tespit etmiştir. Öğrencilerin internetten yararlanma zamanlarının akademik başarılarını etkilemesi, internette bitmeyen veri bulunmasından ve öğrencilerin bu doğrultuda yararlanımlarından kaynaklanmakta, akademik ertelemeleri ise internette boş zaman geçirerek ödevlerini ve görevlerini ertelemelerinden meydana gelmektedir.

Öğrencilerin cinsiyetleri ile akademik erteleme algıları arasındaki fark istatistiksel olarak anlamlı bulunmuştur $(\mathrm{p}<0.05)$. Akademik erteleme davranışlarında cinsiyet değişkeninin anlamlı bir etkisi olmuştur. Erkeklerin akademik erteleme algıları kadınlara göre daha yüksektir. Deniz (2012), çalışmasında kız öğrencilerin "Facebook kullanım amacı ölçeği” puan ortalamalarının erkeklere oranla daha düşük olduğunu belirlemiştir. Akkuş (2018) 8'inci sınıf öğrencilerinin facebook tutumu ile akademik erteleme davranışları arasındaki ilişkinin incelenmesi üzerine yaptığı araştırmasında, erkeklerin facebook benimseme puanlarının $(x=2,746)$, kadınların facebook benimseme puanlarından $(x=2,545)$ daha yüksek olduğunu tespit etmiştir. Bu çalışmada, öğrencilerin cinsiyetleri ile internet bağımlılığı algıları arasındaki fark istatistiksel olarak anlamlı bulunmuştur $(\mathrm{p}<0.05)$. Erkeklerin internet bağımlılığı algıları kadınlara oranla daha yüksektir. Araştırmada, erkeklerin hem akademik erteleme göstermeleri hem de internet bağımlılığı algılarının kız öğrencilere oranla yükssek olması, öğrenciler için duygusal, sosyal, bedensel gelişimin yaşandığı adölesan dönemde, kimlik bulma duygu ve düşüncesinin ilk planda bulunması gibi nedenlerle, kılara göre ailede serbest yetiştirilen erkek öğrencilerin üniversite ortamında farklı sosyal aktivitelere ve mesleki çalışmalara yönelmeyerek internete ağırlık verdikleri düşünülebilir. Seferoğlu ve Yıldız (2013), gerçekleştirdikleri araştırmalarında kız öğrencilerin sosyal medya bağımlılıklarının erkek öğrencilere oranla daha az olduğunu ifade etmişlerdir. Uzun (2016), farklı liselere devam eden ergenlerin facebook bağlanma stratejileri ve akademik erteleme davranışları arasındaki ilişskinin incelenmesine yönelik yaptığı araştırmasında, erkek öğrencilerin akademik erteleme düzeylerini kız öğrencilere göre daha yüksektir bulmuştur. Kız öğrencilerin erkek öğrencilere 
kıyasla yetişme şekilleri değerlendirildiğinde, kızların toplumsal normlarla sınırları çizilmiş ve daha denetimli yetiştiğini müşahede edebiliriz. Kızların erkeklere göre daha denetim altında yetişmeleri nedeniyle gelecek dönemlerde akademik erteleme gibi sorunsal tablonun, daha özgür yetiştirilen erkeklere kıyasla kızlarda daha düşük seviyede gözlemlendiğini söyleyebiliriz.

Öğrencilerin akademik erteleme ve internet bağımlılığı algılarının öğrenim durumlarına göre farklılığın istatistiksel olarak anlamlı olmadığı belirlenmiştir $(\mathrm{p}>0,05)$. Birinci öğretimdeki öğrencilerin, ikinci öğretimdekilere oranla akademik erteleme puan ortalamaları daha yüksek bulunmuştur. İkinci öğretimdekilerin katlanmış oldukları eğitim zaman ve maliyet farklılı̆̆ı, birinci öğretime göre daha az akademik ertelemede bulunduklarını düşündürebilir. Kınık (2015) üniversite öğrencilerinin akademik erteleme davranışları ile fonksiyonel olmayan tutumları üzerine yapmış olduğu araştırmasında, alana göre öğrencilerin akademik erteleme davranışlarında farklılıklar olduğunu belirlemiştir.

Öğrencilerin akademik erteleme algılarının alttan ders alma durumuna göre farklılı̆̆ 1 istatistiksel olarak anlamlı bulunmuştur $(p<0,05)$. Alttan ders alanların akademik erteleme alg1ları alttan ders almayanlara göre daha düşüktür. Diğer taraftan öğrencilerin internet bağımlılı̆̆ı algılarının alttan ders alma durumuna göre farklılığı istatistiksel olarak anlamlı bulunmamıştır $(p>0,05)$. Alttan ders alan öğrencilerin eğitimlerinin farkına vardıkları, eğitimlerine yönelmedikleri taktirde eğitim hayatlarının sona ereceği endişesiyle akademik ertelemede bulunmadıklarını söyleyebiliriz.

Öğrencilerin akademik erteleme algıları yaş gruplarına göre istatistiksel olarak anlamlı bulunmamıştır $(\mathrm{p}>0,05)$. Diğer taraftan, öğrencilerin internet bağımlılığı algılarının yaş gruplarına göre istatistiksel olarak anlamlı olduğu belirlenmiştir $(p<0,05) .19$ yaş ve altı olanların internet bağımlılığı algıları 21 yaşında olanlara göre daha yüksektir. 23 yaş ve üzeri olanların internet bağımlılığı algıları 20 ve 21 yaşında olanlara göre daha yüksektir. Üniversite öğrencilerinde 19 yaş ve altı olanların diğer yaş guruplarına göre internet kullanımı yönünden daha bağımlı olmalarının nedeni, aile yanından ayrılarak daha özgür bir ortamla tanışmaları ve kendi benliğini bulmaları adına internet üzerinden iletişim ve paylaşımlarla, asıl yapmaları gereken görevlerini aksattıkları ve bunun sonucunda akademik ertelemeye maruz kaldıkları söylenebilir.

Öğrencilerin akademik erteleme ve internet bağımlılığı algılarının sınıf gruplarına göre istatistiksel olarak anlamlı olmadığ belirlenmiştir ( $>>0,05)$. Oran (2016) yapmış olduğu Anadolu lisesi öğrencilerinde akademik erteleme davranışının incelenmesi konulu 
araştırmasında akademik ertelemenin sınıf gruplarına göre farklılaşmadığını tespit emiştir. Arslan (2013) ve Akdemir de araştırmasında benzer sonuç bulmuştur. Yiğit ve Dilmaç (2011) araştırmalarında, öğrencilerin akademik ertelemeleri ile okumakta oldukları sınıf düzeyleri arasında anlamlı bir farklılık saptamamışlardır. Bu çalışmanın bulgularının tersine, alanyazında sınıf seviyelerine göre akademik erteleme tutumlarının anlamlı düzeyde farklılaştığına dair araştırmalar da bulunmaktadır. Berber Çelik ve Odacı (2015) akademik erteleme davranışının bazı kişisel ve psikolojik değişkenlere göre açıklanmasıyla ilgili yaptıkları araştırmalarında, akademik ertelemenin sınıf düzeylerine göre anlamlı farklılık gösterdiğini tespit etmişlerdir. Sınıf düzeyinin yükseldikçe akademik ertelemenin arttığını belirlemişlerdir. Doğan, Kürüm ve Kazak (2014) gerçekleştirdikleri kişilik özelliklerinin erteleme davranışını yordayıcılığıyla ilgili araştırmalarında benzer sonuçlar bulmuştur. Sınıf düzeyleri arttıkça akademik ertelemenin artmasının nedeni, ailelerin, sınıf düzeyleriyle birlikte yaşları da ilerleyen öğrencilerle biraz daha az ilgilenmeleri ve okul takiplerini azaltmaları olarak düşünülebilir. Ayrıca sınıf seviyeleri artan öğrencilerin ders yükü de artacak ve zamanında üzerinde durulmayan derslerin birikimi sonucunda zorlanan öğrenci akademik ertelemeye maruz kalabilecektir. Uzun araştırmasında, 11'inci sınıf öğrencilerinin akademik erteleme puanlarının, 9'uncu sınıf öğrencilerinden daha yüksek olduğuna ulaşmıştır.

Öğrencilerin akademik erteleme algıları GANO değişkeni gruplarına göre istatistiksel olarak anlamlı bulunmuştur ( $<<0,05)$. GANO puanı 2,00 ve altı olanların akademik erteleme algıları 3,51-4,00 olanlara göre daha düşüktür. 2,01-2,50 olanların akademik erteleme algıları 3,01-3,50, 3,51-4,00 olanlara göre daha düşüktür. Diğer taraftan öğrencilerin internet bağımlılığı algıları GANO değişkeni gruplarına göre istatistiksel olarak anlamlı bulunmuştur $(\mathrm{p}<0,05)$. GANO puanı 3,51-4,00 olanların internet bağımlılığ 2,51-3,00, 3,01-3,50 olanlara göre daha düşüktür. Öğrenci not ortalamaları yükseldikçe internet bağımlılığının azaldığını söyleyebiliriz. Başka bir deyişle, not ortalaması yüksek olan öğrenciler interneti gerekli olduğunda kullanmaktadır. Not ortalaması yüksek olan öğrenciler her ne kadar interneti az kullansalar da, akademik ertelemelerinin diğer gruplara oranla yüksek olduğunu görüyoruz. Bu akademik ertelemenin nedeninin internet bağımlılığının olmayacağını ve daha çok sosyal ve fiziksel aktivitelere zaman ayırmaları ve bu durumunda notları anlamında değerlendirildiğinde not ortalamalarının yüksek olması nedeniyle akademik başarıyı getirdiğini söyleyebiliriz. Can (2018) yapmış olduğu araştırmasında öğrencilerin not ortalamalarının arttıkça akademik erteleme davranışlarının azaldığını tespit etmiştir. Kim ve Seo (2015) akademik erteleme ve akademik başarı arasındaki bağlantıyı araştırdığında not ortalaması ve 
erteleme arasındaki bağlantının, dışarıdan değerlendirilen akademik performans ve erteleme arasındaki bağlantıdan daha zayıf olduğu bulgusunu elde etmişlerdir. Steel, Brothen ve Wambach (2001) ise, erteleme tutumu gösteren öğrencilerin genellikle erteleme tutumu göstermeyen öğrenciler kadar çalışmayı arzu ettiklerini, her şeyden önce bir projenin başlama evresinde bunu elde etmede sıkıntı yaşadıklarını, hedeflediklerinden minimum seviyede performans sergilediklerini ama dersin bitimine veya projenin teslim tarihine yaklaştıkça daha çok çalışmak için efor sarf ettiklerini belirtmekte, bunun sebebini ise işin bitirilme zamanıyla ilgili ussal olmayan düşünce şekline bağlamaktadır. Bu nedenle çalışmak için gerekli vakit azalmakta ve öğrencilerin derslerine yönelik notları olması gerekenden daha düşük olmaktadır. Yaptığımız araştırmada not ortalaması 2 ve altı olan öğrencilerin akademik ertelemelerinin, yüksek puanlı öğrencilere göre düşük olduğu belirlenmiştir. Düşük not alan öğrenciler akademik erteleme yapmamakla birlikte, Steel, Brothen ve Wambach (2001) yapmış oldukları çalışma sonuçlarına istinaden, çok efor sarf ettiklerini fakat işin sonlanma zamanıyla ilgili akılcı olmayan düşünce biçimlerinin etkisinde kaldıkları düşünülebilir.

Sivas il merkezinde yer alan Cumhuriyet Üniversitesi Sağlık Bilimleri Fakültesi, Sağlık Hizmetleri Yüksekokulu sağlık yönetimi bölümünde okuyan üniversite öğrencilerinin hem akademik davranışları hususunda, kendi eğitimleri kadar başkalarına model teşkil etme gibi bir misyonlarının mevcut olması yanında, akademik erteleme davranışlarının internet bağımlılık düzeyleri açısından nasıl açıklandığının hem kendi eğitimleri açısından hem de diğer öğrencileri negatif akademik ertelemeye teşvik etme açısından sahip oldukları bilinç düzeyinin incelenmesini amaçlayan bu araştırmanın sonuçlarına göre;

Araştırmaya katılan kişilerin demografik dağılımları incelendiğinde; \%66,7'si kadın, \%33,3'ü erkek, \%20,7'si 19 yaş altı, \%18'i 20,\%23'ü 21, \%19,4'ü 22, \%18,9'u 23 yaş ve üzeri olarak belirlenmiştir. Katılımcıların \%28,4'ü 1'inci sınıf, \%24,8'i 2'nci sınıf, \%24,8'i 3'üncü sınıf, \%22,1'i 4'üncü sınıftır. \%49,5'i birinci öğretim, \%50,5'i ikinci öğretimde eğitim görmektedir. Genel akademik not ortalama dağılımları (GANO) incelendiğinde \%9'u 2,00 ve altı, \%24,8’i 2,01-2,50, \%37,8'i 2,51-3,00, \%22,1’i 3,01-3,50, \%6,3’ü 3,51-4,00 aralı̆̆ındadır. \%68,9’u alttan ders alırken, \%31,1'inin alttan dersi bulunmamaktadır.

Akademik erteleme ölçeği genelinden alınabilecek puan ortalamaları 2,98 $\pm 0,75$ 'dir.

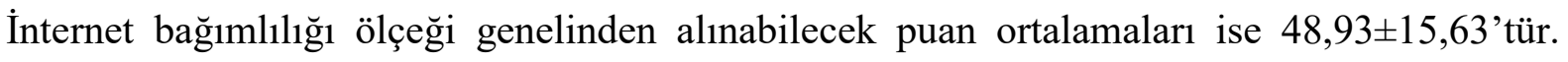
Araştırma kapsamındaki öğrencilerin \%51,4'ü internet bağımlısı değil, \%45,5'i riskli kullanıcı, \%3,2'si ise internet bağımlısı olarak belirlenmiştir. Genel ölçekler arasındaki ilişki incelendiğinde; akademik erteleme ile internet bağımlılığı arasında negatif yönde düşük 
kuvvetli bir ilişki olduğu belirlenmiştir. Regresyon analizi sonuçları incelendiğinde: internet bağımlılığının akademik erteleme üzerinde anlamlı bir etkiye sahip olduğu görülmektedir. İnternet bağımlılığının akademik ertelemeyi \%14,2 oranında açıkladığı belirlenmiştir.

Öğrencilerin cinsiyetlere göre akademik erteleme ve internet bağımlılığı davranışlarını incelediğimizde, erkeklerin $(\bar{x}=3,08)$ akademik erteleme algıları kadınlara $(\bar{x}=2,83)$ göre daha yüksek, kadınların $(\bar{x}=45,52)$ internet bağımlılığı algıları erkeklere $(\bar{x}=55,77)$ göre daha düşük bulunmuş olup, gruplar arasındaki fark istatistiksel açıdan anlamlı bulunmuştur.

Öğrencilerin öğrenim türüne göre akademik erteleme ve internet bağımlılığ davranışlarını incelediğimizde, akademik erteleme ve internet bağımlılığı algılarının öğrenim durumuna göre farklılığı istatistiksel olarak anlamlı bulunmamıştır.

Öğrencilerin alttan ders almalarına göre akademik erteleme ve internet bağımlılı̆̆ davranışlarını incelediğimizde, alttan ders alanların $(\bar{x}=2,89)$ akademik erteleme algıları alttan ders almayanlara $(\bar{x}=3,17)$ göre daha düşük olup gruplar arasındaki fark istatistiksel açıdan anlamlı bulunmuştur. Öğrencilerin internet bağımlılığı algılarının alttan ders alma durumuna göre farklılığı istatistiksel açıdan anlamlı bulunmamıştır.

Öğrencilerin yaş gruplarına göre akademik erteleme ve internet bağımlılığı davranışlarını incelediğimizde, akademik erteleme algılarının yaş gruplarına göre istatistiksel olarak anlamlı olmadığı belirlenmiştir. Öğrencilerden 19 yaş ve altı olanların $(\bar{x}=51,39)$ internet bağımlılığı algıları 21 yaşında $(\bar{x}=45,03)$ olanlara göre daha yüksektir. 23 yaş ve üzeri olanların $(\bar{x}=54,21)$ internet bağımlılığı algıları $20(\bar{x}=46,12)$ ve 21 yaşında $(\bar{x}=45,03)$ olanlara göre daha yüksek olup, gruplar arasındaki fark istatistiksel açıdan anlamlı bulunmuştur.

Öğrencilerin sınıf gruplarına göre akademik erteleme ve internet bağımlılığı davranışlarını incelediğimizde, akademik erteleme ve internet bağımlılığı algılarının sınıf gruplarına göre istatistiksel olarak anlamlı olmadığı belirlenmiştir.

Öğrencilerin GANO'larına göre akademik erteleme ve internet bağımlılığ1 davranışlarını incelediğimizde, GANO puanı 2,00 ve altı olanların $(\bar{x}=2,73)$ akademik erteleme alg1ları 3,51-4,00 ( $\bar{x}=3,52)$ olanlara göre daha düşüktür. 2,01-2,50 olanların $(\bar{x}=2,72)$ akademik erteleme algıları 3,01-3,50 ( $\bar{x}=3,31), 3,51-4,00(\bar{x}=3,52)$ olanlara göre daha düşük olup, gruplar arasındaki fark istatistiksel açıdan anlamlı bulunmuştur. GANO puanı 3,51-4,00 ( $\bar{x}=32,57)$ olanların internet bağımlılı̆̆ algıları 2,00 ve altı $(\bar{x}=51,00), 2,01-2,50(\bar{x}=51,61), 2,51-3,00$ $(\bar{x}=49,69), \quad 3,01-3,50(\bar{x}=48,46)$ olanlara göre daha düşük olup, gruplar arasındaki fark istatistiksel açıdan anlamlı bulunmuştur.

\section{Öneriler}


Üniversite öğrencilerine ve üniversite ortamına gelmeden önceki okul dönemleri olan lise ve ortaokul öğrencilerine, ailelere ve öğretmenlere yönelik akademik erteleme, internet bağımlılığı ve sağlıklı internet kullanımı gibi konularda eğitimler düzenlenebilir, broşürlerle süreklilik sağlanabilir ve kamu spotuyla desteklenebilir.

Üniversite yönetimleri, öğrencileri sosyal aktivitelere yönlendirme adına okul kulüplerinin işlevsel olarak en üst seviyede uygulamaya dönük olmalarını sağlayabilirler. Okul kulüpleriyle ilgili iç kontrol başlatılıp haftalık ve aylık faaliyet planlarının istenmesiyle kontrolleri sağlanabilir.

Araştırma daha büyük örneklem grubunda ve değişik fakültelerde aynı anda yapılabilir.

\section{Makalenin Bilimdeki Konumu}

Sağlık Bilimleri, Sağlık Yönetimi ve Bilinç Düzeyi

\section{Makalenin Bilimdeki Özgünlüğü}

$\mathrm{Bu}$ çalışmada tanımlayıcı tipte ve kesitsel olarak elde edilen bilgiler, üniversite öğrencilerinin, akademik erteleme davranışlarının internet bağımlılık düzeyleri açısından nasıl açıklandığının hem kendi eğitimleri açısından hem de diğer öğrencileri negatif akademik ertelemeye teşvik etme açısından sahip oldukları bilinç düzeyleri konusunda farkındalıklarına katkı sunacaktır.

\section{Kaynaklar}

Ackerman, David, S., Barbara, L. Gross. (2005). My instructor made me do it: task characteristics of procrastination. Journal of Marketing Education. 27(2), 5-13.

Akdemir, N.T. (2013). İlköğretim öğrencilerinin facebook tutumlart ile akademik erteleme davranışları ve akademik başarıları arasındaki ilişkilerin incelenmesi. Yüksek Lisans Tezi. Marmara Üniversitesi, Eğitim Bilimleri Enstitüsü, İstanbul

Akkuş, R. (2018). 8.Sınıf ögrencilerinin facebook tutumu ile akademik erteleme davranışları arasındaki ilişkinin incelenmesi (Balıkesir İli Merkez İlçeler Örneği). Yüksek Lisans Tezi. Balıkesir Üniversitesi, Sosyal Bilimler Enstitüsü, Eğitim Bilimleri Ana Bilim Dalı, Eğitim Programları ve Öğretim Bilim Dalı, Balıkesir 
Alloway, T. P., Horton, J., Alloway, R. G., ve Dawson, C. (2013). Social networking sites and cognitive abilities: do they make you smarter? Computers \& Education, 63, 10-16. http://doi.org/10.1016/j.compedu.2012.10.030

Amichai-Hamburger, Y. (2013). Youth internet and wellbeing. Computers in Human Behavior, 29 (1), 1-2. http://doi.org/10.1016/j.chb.2012.05.023

Arslan, A. (2013). Lise Öğrencilerinin Akademik Erteleme Davranışlarının Karar Verme Stilleri İle İlişkisi. Yüksek Lisans Tezi. Gaziantep Üniversitesi Eğitim Bilimleri Enstitüsü, Gaziantep

Başak, T., Uzun, Ş. ve Arslan F. (2008). Hemşirelik yüksek okulu öğrencilerinin zaman yönetimi becerileri. Türk Silahlı Kuvvetleri Koruyucu Hekimlik Bülteni, 7(5), 429-434

Bayrak, H. (2019). We are social ve Hootsuit “Digital 2019 in Turkey", https://dijilopedi.com/2019-turkiye-internet-kullanim-ve-sosyal-medya-istatistikleri/ adresinden 19.02.2019 tarihinde alınmıştır.

Bayraktar, F. (2001). Internet kullanımının ergen gelişimindeki rolü. Yüksek Lisans Tezi. Ege Üniversitesi Sosyal Bilimler Enstitüsü, İzmir.

Berber Çelik, Ç. ve Odacı, H. (2015). Akademik erteleme davranışının bazı kişisel ve psikolojik değişkenlere göre açılanması. Hacettepe Üniversitesi Eğitim Fakültesi Dergisi. 30(3), 31-47.

Can, S. (2018). Ergenlerin Akademik erteleme davranışlarl, internet bă̆ımlılı̆̆ ve temel psikolojik ihtiyaçları: bir model önerisi. Yüksek Lisans Tezi. Yıldız Teknik Üniversitesi, Sosyal Bilimler Enstitüsü, Eğitim Bilimleri Ana Bilim Dalı, İstanbul

Cao, H., Sun, Y., Wan, Y., Hao, J., ve Tao, F. (2011). Problematic internet use in chinese adolescents and its relation to psychosomatic smptoms and life satisfaction. Bmc Public Health, 11.

Chou, C. ve Hsiao, M.C. (2000). Internet addiction, usage, gratification and pleasure experience: The Taiwan college students’ Case. Computers\&Education, 35, 65-80.

Chrismore, S., Betzelberger, L.B. ve Tonya C. (2011). Twelve-step recovery in inpatient treatment for internet addiction. internet addiction: a handbook and guide to evaluation and treatment, ed. Kimberly S. Young, Cristiano Nabuco De Abreu. John Wiley \& Sons, 205-222.

Çakıcı, D. Ç. (2003). Lise ve üniversite öğrencilerinde genel erteleme ve akademik erteleme davranışının incelenmesi. Yüksek Lisans Tezi. Ankara Üniversitesi, Eğitim Bilimleri Enstitüsü, Ankara 
Davis, R.A. (2001). A cognitive-behavioral model of pathological internet use. Comput Human Behaviour, 17, 187-195.

Doğan, T., Kürüm, A. ve Kazak, M. (2014). Kişilik özelliklerinin erteleme davranışını yordayıcılığı. Başkent University Journal of Education. 1(1), 1-8.

Ferrari, Joseph R., ve Scher, Steven J. (2000). Toward an understanding of academic and nonacademic tasks procrastinated by students: the use of daily logs. Psychology in the Schools, 37 (4), 359-366.

Gil De Zuniga, H., Puig-I-Abril, E. ve Rojas, H. (2009). Weblogs, traditional sources online and political participation: an assessment of how the internet is changing the political environment. New Media \& Society, 11(4), 553-574.

Goldberg, I. (1996). Internet Addiction Disorder. https://scholar.google.com.tr/scholar?cluster=3874910117513655426\&hl=en\&as_sdt $=0,5$ adresinden 21.10.2018 tarihinde alınmıştır.

Gorra, V. C. ve Bhati, S. (2016). Students’ perception on Use of Technology in the Classroom at Higher Education Institutions in Philippines. Asian Journal of Education and eLearning, 4(3), 92-103.

Gürültü, E. (2016). Lise öğrencilerinin sosyal medya bă̆ımlılıkları ve akademik erteleme davranışları arasındaki ilişkinin incelenmesi. Yüksek Lisans Tezi. Marmara Üniversitesi Eğitim Bilimleri Enstitüsü, İstanbul

Greenfield, D. (2011). The addictive properties of internet usage. internet addiction: a handbook and guide to evaluation and treatment. ed. Kimberly S. Young, Cristiano Nabuco De Abreu. John Wiley \& Sons, 135-153.

International Telecommunication Union [ITU]. (2012). İnternet kullaniciları. https://www.itu.int/en/ITU-D/Statistics/Pages/default.aspx adresinden 19.10.2018 tarihinde alınmıştır.

International Telecommunication Union [ITU]. (2013). 2013 yılı Dünya BİT gerçekleri ve rakamları. Cenevre, İsviçre: Uluslararası Telekomünikasyon Birliği.

Iş1k, I. ve Ergün, G. (2018). Determining the Relation between Turkish MiddleSchool Students' Internet Addiction and Perceived Social Support from Family. Addicta: The Turkish Journal on Addictions, 5(3), 527-542. http://dx.doi. org/10.15805/addicta.2018.5.3.0003

Kakabadse, A., Kakabadse, N., Bailey, S., ve Myers, A., (2009), ‘Techno addicts: young person addiction to technology', Signel Press, [Online], 
Kınık, Ö. (2015). Üniversite öğrencilerinin akademik erteleme davranışları ile fonsiyonel olmayan tutumları, depresyon düzeyleri ve benlik saygıları arasındaki ilişki. Yüksek Lisans Tezi. Karadeniz Teknik Üniversitesi Eğitim Bilimleri Enstitüsü.

Kim, K.R. \& Seo, E.H. (2015). The relationship between procrastination and academic performance: a meta-analysis. Personality and Individual Differences. s. 82, 26-33.

Klassen, Robert M., Ang, Rebecca P., Chong, Wan H., Krawchuk, Lindsey L., Huan, Vivien S., Isabella, Y.F., Wong ve Lay See Yeo. (2010). Academic procrastination in two settings: motivation correlates, behavioral patterns, and negative impact of procrastination in canada and singapore. Applied Psychology: An International Revlew, 59 (3), 361-379

Kwon, Jung-Hye. (2011). Toward the prevention of adolescent internet addiction. internet addiction: a handbook and guide to evaluation and treatment. ed. Kimberly S. Young, Cristiano Nabuco De Abreu. New Jersey: Wiley, 223-244.

Leung, L. (2007). Stressful life events, motives for Internet use, and social support among digital kids. Cyberpsychology \& Behavior, 10(2), 204-214.

Liu, T. C., Desai, R. A., Krishnan-Sarin, S., Cavallo, D. A., ve Potenza, M. N. (2011). Problematic internet use and health in adolescents: data from a high school survey in connecticut. Journal of Clinical Psychiatry, 72(6), 836-845.

Livingstone, S. ve Haddon, L. (2008). Risky experiences for children online: charting european research on children and the internet, Children and Society 22(4), 314-23

Liberatore, K. A., Rosario, K., Colon-De Marti, L. N., ve Martinez, K. G. (2011). Prevalence of internet addiction in latino adolescents with psychiatric diagnosis. CyberPsychology, Behavior and Social Networking, 14(6), 399-402.

Murathan, T. (2018). Identification of internet usage and dependency level of physical education and sport teaching students. International Education Studies, 11(11), 14.

Müller, K. W., Ammerschläger, M., Freisleder, F. J., Beutel, M. E., ve Wölfling, K. (2012). Addictive internet use as a comorbid disorder among clients of an adolescent psychiatry - prevalence and psychopathological symptoms. Zeitschrift für Kinder- und Jugendpsychiatrie und Psychotherapie, 40(5), 331-339.

Ocak, M. A. (2012). Türkiye'de internet kullanım trendleri. Gazi Üniversitesi, Gazi Eğitim Fakültesi, Bilgisayar ve Öğretim Teknolojileri Eğitimi Bölümü, https://www.tbmm.gov.tr/arastirma_komisyonlari/bilisim_internet/docs/sunumlar/23_ 
05\%20-\%20Mutlu\%20Cocuklar\%20Dernegi.pdf adresinden 20.10.2018 tarihinde alınmıştır.

Odac1, H. ve Berber Çelik, Ç. (2012). Relationship between university students’ problematic 1nterent use and their academic self efficacy, Academic Procrastination and Aating Attitudes. Education Sciences. 7(1), 389-403.

Oran, S. (2016). Anadolu lisesi ögrencilerinde akademik erteleme davranışının incelenmesi. Yüksek Lisans Tezi. Çağ Üniversitesi, Sosyal Bilimler Enstitüsü. Mersin

Park, S. K., Kim, J. Y., ve Cho, C. B. (2008). Prevalence of Internet Addiction and Correlates with Family Factors Among South Korean Adolescents. Adolescence, 43(172), 895909.

Paul, J.A, Baker, H.M. ve Cochran, J.D. (2012). Effect of online social networking on student academic performance. Computers in Human Behavior, 28, 2117-2127.

Pınar Bölüktaş, R., Özer, Z. ve Yıldırım, D. (2019). Web tabanlı eğitimin sağlık alanında kullanılabilirliği, Journal of International Management and Social Researches, 6(11), 198-207.

Rabin, Laura A., Fogel Joshua, ve Nutter-Upham, Katherine E. (2011). Academic procrastination in college students: the role of self-reported executive function. Journal of Clinical and Experiımetal Neuropsychology, 33(3), 344-357.

Ritchel, M. (2003). 'The lure of data: Is it addictive?'. New York Times, http://www.nytimes.com/2003/07/06/business/the-lure-of-data-isit-addictive.html adresinden 19.10.2018 tarihinde alınmıştır.

Seferoğlu, S.S. ve Yıldız, H. (2013). Dijital çağın çocukları: ilköğretim öğrencilerinin facebook kullanımları ve internet bağımlılıkları üzerine bir araştırma. İletişim ve Diplomasi, 2, 31-48.

Seo Hocası. (2019) Google, 2017'de en çok aranan terimleri açıkladı!, https://www.seohocasi.com/google-2017de-en-cok-aranan-terimleri-acikladi/ adresinden 19.02.2019 tarihinde alınmıştır.

Sirois, Fuschia M. (2016). Conceptualizing the relations of procrastination to health and wellbeing. Procrastination, Health and Wellbeing. ed. Fuschia M. Sirois, Timothy A. Pychyl. Academic Press. 3-20.

Solomon, Laura J., Esther D. Rothblum. (1984). Academic procrastination: frequency and cognitive-behavioral correlates. Journal of Counseling Psychology. 31(4), 503. 
Steel, P., Brothen, T. \& Wambach, C. (2001). Procrastination and personality, performance, and mood. Personality and individual differences. 30(1), 95-106.

Türkiye İstatistik Kurumu [TÜİK]. (2017). Hanehalkı bilişim teknolojileri kullanım araştırması， http://www.tuik.gov.tr/HbPrint.do?id=24862 adresinden 19.10.2018 tarihinde alınmıştır.

Uzun A.E. (2016). Farklı liselere devam eden ergenlerin facebook bağlanma stratejileri ve akademik erteleme davranışları arasındaki ilişkin incelenmesi. Yüksek Lisans Tezi. İstanbul Aydın Üniversitesi, Sosyal Bilimler Enstitüsü, Psikoloji Ana Bilim Dalı, İstanbul

Uzun, A.M., Ünal, E., ve Tokel, S.T. (2014). Exploring internet addiction, academic procrastination and general procrastination among pre-service ICT teachers. Mevlana International Journal Of Education. 4(1): 189-201.

Yiğit ve Dilmaç (2011). Ortaöğretimde öğrencilerinin sahip oldukları insani değerler ile akademik erteleme davranışlarının bazı değişkenler açısından incelenmesi, Dumlupınar Üniversitesi Sosyal Bilimler Enstitüsü Dergisi, 31, 159-178.

Young, K. (1999). Internet addiction: symptoms, evaluation and treatment. In L. V. T. L. Jackson (Ed.), Innovations in clinical practice. Sarasota, FL: Professional Resource Press.

Young, K. S. (1996). "Psychology of computer use: XL. addictive use of the internet: a case that breaks the stereotype." Psychological Reports 79(3), 899-902.

\section{Summary}

\section{Statement of Problem}

The Internet plays more roles in our lives. This situation is taking place in the life of the younger generation rather than the adults. Personal computers are therefore used by billions of people in every aspect of their personal and professional lives. The increasing popularity and frequency of Internet use has led to the emergence of clinical cases showing signs of abuse. It is stated that internet addiction is a primary and progressive disease like the drug addiction. Although there are addictive features of the addictive behaviour, the Internet and digital technologies are known for the fun features. For this reason, a pleasant mood change increases the likelihood of later use. Internet addiction is a psychological dependence and especially young people are at risk of this addiction. Excessive use of the Internet can cause health 
problems, the relationship problems and time management problems. Problematic internet use is a psychiatric condition that includes discordant thoughts and pathological behaviours. Continuous data flow will not only hinder productivity, disrupt family harmony, but more importantly, in most cases it may become a very difficult addiction to stop Recent studies have revealed that technology addiction among adolescents has a devastating impact on learning. Adolescents are at risk of developing Internet addiction because of their variability in developing cognitive controls and constructing skills. Academic postponement is defined as not being ready for examinations, not preparing periodic assignments, not fulfilling the administrative plans related to school and leaving the main academic tasks to the last minute. The maximum frequency of quitting, retiring or inadequate learning are the results of academic postponement. The level of awareness that university students have needs to be examined in terms of encouraging academic postponement behaviours and their level of internet addiction, both in terms of their own education and in encouraging other students to negative academic postponement. For this reason, it is aimed to measure the effect of internet addiction levels on academic postponements of university students studying in health management department and to determine whether internet addiction levels and academic postponement differ according to socio-demographic characteristics of students.

\section{Method}

The research has been planned and constructed in the health management department of Health Sciences Faculty of Sivas Cumhuriyet University between May and June 2018. The population of the study consists of 222 university students studying in the 1st, 2nd, 3rd and 4th grades in the health management department in the 2017-2018 academic year. As the data collection tools, a questionnaire consisting of 6 questions for the determination of the characteristics of the university students, The Internet Addiction Scale (IAS) consisting of 20 questions and the Academic Procrastination Scale (APS) consisting of 19 questions were used. Statistical analysis of the data was done by using the Statistical Package for Social Sciences (SPSS) 17.0 package program. The suitability of the IAS and APS scores to the normal distribution were analyzed with Single Sample Kolmogorov Smirnov and Shapiro-Wilk Tests. T-test, One-Way ANOVA, Post-Hoc Scheffe and LSD tests were performed and $\mathrm{p}<0.05$ was considered significant. Pearson correlation was used to determine the relationship between the 
scales and regression analysis was used to test the effect of Internet addiction on academic postponement.

\section{Findings}

When the demographic distributions of the participants were examined, it is determined that $66.7 \%$ are females, $33.3 \%$ are males, $20.7 \%$ are females under $19,18 \%$ are $20,23 \%$ are $21,19.4 \%$ are $22,18.9 \%$ are above 23 years and older. $28.4 \%$ of the participants are 1 st grade, $24.8 \%$ are 2 nd grade, $24.8 \%$ are 3rd grade, $22.1 \%$ are 4 th grade. $49,5 \%$ of the students are educated in primary education and 50,5\% are in secondary education. When the average academic grade average distributions (GANO) are examined, 9\% are 2,00\%, 24,8\% are 2,012,50, 37,8\% are 2,51-3,00, 22,1\% are 3.01-3.50, 6.3\% are 3.51-4.00. 68.9\% of them take courses from lower classes, $31.1 \%$ of them do not have any courses from lower classes (Table 1).

The mean score of the academic procrastination scale is $2.98 \pm 0.75$. (Table 3). It is determined that the difference of academic procrastination of students according to gender was statistically significant as 95\% confidence level $(t=2,075 ; \mathrm{p}<0,05)$. Men's academic procrastination perception $(\bar{x}=\mathbf{3 , 0 8})$ is higher than women $(\bar{x}=\mathbf{2 , 8 3})$ (Table 4). The students' academic procrastination level is statistically significant as 95\% confidence level according to the status of taking courses from lower classes $(\mathrm{t}=-2,556 ; \mathrm{p}<0,05)$. The academic procrastination perceptions of students taking courses from lower classes $(\bar{x}=\mathbf{2 , 8 9})$ are lower than those who do not take courses $(\bar{x}=3,17)$ (Table 6). It is determined that academic procrastination perception is statistically significant as 95\% confidence level according to GANO variable groups $(F=7,089 ; p<0,05)$. As a result of the Scheffe test, those with a GANO score of 2.00 or less have a lower level of academic procrastination $(\bar{x}=2,73)$ than those with a score of 3.51-4.00 $(\bar{x}=3,52)$. Academic procrastination of those with $2.01-2.50(\bar{x}=2,72)$ is lower than those with 3.01-3.50 ( $\bar{x}=3,31)$ and 3.51-4.00 ( $\bar{x}=3,52)$ (Table 9).

The average of the internet addiction scale is $48.93 \pm 15.63$ (Table 10). $51.4 \%$ of the students are not internet addicts, 45.5\% are risky users and 3.2\% are internet addicts. (Table 11). The students' perceptions of internet dependence are statistically significant as $95 \%$ confidence level $(\mathrm{t}=-4,832 ; \mathrm{p}<0,05)$. Internet addiction perceptions of women $(\bar{x}=\mathbf{4 5 , 5 2})$ are lower than men $(\bar{x}=55,77)$ (Table 12). Students' perceptions of internet addiction are statistically significant as 95\% confidence level compared to age groups $(F=2,688 ; p<0,05)$. As a result of the LSD test, those aged 19 years or younger $(\bar{x}=\mathbf{5 1 , 3 9})$ have higher internet 
addiction perceptions than those aged $21(\bar{x}=\mathbf{4 5 , 0 3 )}$. Internet addiction perceptions of those aged 23 and over are higher $(\bar{x}=\mathbf{5 4 , 2 1})$ than those of $20(\bar{x}=\mathbf{4 6 , 1 2}), 21$ years $(\bar{x}=\mathbf{4 5 , 0 3})$ (Table 15). Students' perceptions of internet addiction were statistically significant at $95 \%$ confidence level according to GANO variable groups $(F=4,678 ; p<0,05)$. As a result of the Scheffe test, Scheffe those with a GANO score of 3,51-4,00 ( $\bar{x}=32,57)$ have lower internet addiction perceptions than those with 2,00 and below GANO scores $(\bar{x}=\mathbf{5 1 , 0 0}) 2,01-2,50(\bar{x}=\mathbf{5 1 , 6 1})$, 2,51-3,00 ( $\bar{x}=\mathbf{4 9 , 6 9}), 3,01-3,50(\bar{x}=\mathbf{4 8 , 4 6})$ (Table 17).

It is determined that there is a negative correlation between academic postponement and internet addiction $(\mathrm{p}<0.01, \mathrm{p}=0,000, \mathrm{r}=-0,382)$ (Table 18). When the results of regression analysis are examined, it is seen that internet addiction has a significant effect on academic postponement. It is determined that internet addiction explains academic postponement (0.05\%) by $14.2 \%$. (Table 19$)$.

\section{Discussion and Conclusion}

The mean score of the academic postponement scale is 2,98 $\pm 0,75$ (Table 3). The average of the Internet addiction scale is $48.93 \pm 15.63$ (Table 10). It is determined that $51.4 \%$ of the students are not internet-addict, $45.5 \%$ are risky users and 3.2\% are internet addicts. (Table 11). When the relationship between general scales is examined, it is determined that there is a negative correlation between academic postponement and internet addiction ( $<<0.01$, Table 18). In his study, Akdemir (2013) found that there is a 50.1\% correlation between students' academic attitudes and academic procrastination. As students' Facebook behaviours increase, their academic postponements increase. In their studies Paul, Baker and Cochran (2012) stated that students who use their Facebook accounts frequently have higher academic procrastination scores than students who rarely use them. When the results of regression analysis are examined, it is seen that internet addiction has a significant effect on academic postponement. It has been determined that internet addiction explains academic postponement (0.05\%) by $14.2 \%$ (Table 19$)$. In his study Gürültü (2016) found a significant positive relationship between social media addiction and academic postponement, and found that social media addiction accounted for approximately 19\% of academic procrastination behaviour. In terms of time, the effect of Students' benefitting from Internet arises from endless information on the net and the students' benefiting from it, on the other hand, their academic postponements result in their spending leisure time on the internet and postponing their duties.

The difference between students' gender and academic procrastination is statistically significant $(\mathrm{p}<0.05)$ (Table 4). The gender variable has a significant effect on academic 
procrastination. Males have higher academic procrastination than females. Deniz (2012) states that the mean score of the female students' use of Facebook scale is lower than that of males. Akkuş (2018) in the study conducted by 8th grade students on the attitude of Facebook and academic procrastination behaviours, it is determined that the Facebook adoption scores ( $\mathrm{x}=$ $2,746)$ of males are higher than the females' Facebook adoption scores $(x=2,545)$. In this study, the difference between students' gender perception and internet addiction has been found statistically significant $(\mathrm{p}<0.05)$ (Table 12). Males' perception of internet addiction is higher than females. In the study, both males' academic procrastination and their internet addiction perceptions' being higher than female students' in the adolescent period where emotional, social and physical development is experienced for students, it is thought that the male students who are free in the family have not focused on different social activities and professional studies in the university environment. Seferoğlu and Yıldız (2013) reported that social media addictions of female students are less than male students. Uzun (2016) in the study of adolescents attending different high schools for the study of the relationship between Facebook attachment strategies and academic procrastination behaviours found that the academic procrastination levels of male students are higher than female students. When female students' growing forms compared to male students, we can observe that the girls are bordered by social norms and they are more supervised. Because girls are more under control than boys, in later periods, for problematic table like academic postponement we can say that girls are observed at lower levels compared to males grown more free.

The students' academic postponement perceptions are found to be statistically significant when compared to the condition of their taking courses from lower classes $(p<0,05$, Table 6). The level of academic procrastination of those who take courses from lower classes is lower than the ones who do not take the courses. On the other hand, it is determined that the students' perceptions of internet addiction is not statistically significant ( $>>0,05$, Table 14). We can say that the students who take the courses from the lower classes are aware of their education and do not postpone their academic studies due to the fear of ending their education.

Students' perceptions of internet addiction are found to be statistically significant compared to age groups $(\mathrm{p}<0,05$, Table 15). Internet addiction perceptions of those under 19 are higher than those of 21-year-olds. Internet addiction perception of those who are 23 and older is higher than those of 20 and 21 years old. The reasons why university students are more addictive to the use of the Internet than those of the other age groups are that leaving from their families to meet a more free environment and finding their own identity on the Internet to 
communicate and share, they disrupt their duties and as a result they are subject to academic postponement.

The academic procrastination perception of the students is statistically significant compared to the GANO variable groups ( $<<0,05$, Table 9). Those who have a GANO score of 2.00 or less are less likely to have academic procrastination than the ones with 3.51-4.00. The academic procrastination of those who have 2,01-2,50 are lower than those of 3,01-3,50, 3,514,00. On the other hand, the students' perceptions of internet addiction are statistically significant compared to GANO variable groups $(\mathrm{p}<0,05$, Table 17$)$. Those who have internet addiction perceptions with a GANO score of 3.51-4.00 are lower than those with 2.00 and below, 2.01-2.50, 2.51-3.00, 3.01-3.50. As the students' grade point averages increase, we can say that internet addiction has decreased. In other words, students with high GPA are using the Internet when necessary. Students with high GPAs, although they use the Internet a little, we see that the academic postponement is higher than the other groups. In his research, Can (2018) found that academic grade deferral behaviours decreased as the students' grade point averages increased. When Can (2018) Kim and Seo (2015) investigated the link between academic procrastination and academic achievement, they found that the link between GPA and postponement is weaker than the link between externally evaluated academic performance and postponement. Steel, Brothen and Wambach (2001), on the other hand, assert that the students who show deferment attitude generally want to study as much as the students who do not show deferment, first of all, they are experiencing difficulties in getting it in the starting phase of a project, they perform less than they aim to reach, but they are trying to work harder as they approach the end of the course or the deadline of the project, and for the reason they indicate the students' non-rational way of thinking about the time of completion. Therefore, the time required for work decreases and the grades of the students are less than they should be. In our study, it is determined that the academic postponements of the students with a grade point average of 2 and below are lower than those with high scores. As a result of a study of Steel, Brothen and Wambach (2001) although students who took lower grades did not postpone academically, Steel, Brothen and Wambach (2001) stated that they have made a lot of effort based on the results of their studies, but it may be thought that the students are influenced by unreasonable ways of thinking about the end of their studies.

As a result, trainings can be organized on issues such as academic postponement, internet addiction and healthy internet use for university, high school and secondary school students, their families, and teachers, the continuity of the process can be provided with 
brochures and it can be supported by public spot. University administrations can ensure that the social clubs of the universities become functionally at the highest level in order to guide students towards social activities. Internal control of school clubs can be initiated and they can be checked by requesting weekly and monthly activity plans. This study can be done in larger sample groups and in different faculties at the same time. 